\title{
Vertical slip rates of active faults of southern Albania inferred from river terraces
}

\author{
Oswaldo Guzmán ${ }^{1,2, \star}$, Jean-Louis Mugnier², Riccardo Vassallo², \\ Rexhep Koçi ${ }^{3}$, François Jouanne ${ }^{2}$ \\ ${ }^{1}$ Universidad Simon Bolivar, Departamento de Ciencias de la Tierra, Caracas, Venezuela \\ ${ }_{2}^{2}$ ISTerre, Université de Savoie, CNRS, Le Bourget du Lac, France \\ ${ }^{3}$ Institute of Seismology of Albania, Tirana, Albania
}

\author{
Article history \\ Received October 4, 2012; accepted December 20, 2013. \\ Subject classification: \\ Albania, Albanides, River terraces, Incision rate, Active faults, Vertical slip rate.
}

\begin{abstract}
Fluvial terraces of Shkumbin, Devoll, Osum and Vjosa rivers (southern Albania and northwestern Greece) are studied in order to quantify the vertical slip rates of the large active faults of the Dinaric-Albanic-Hellenic Alpine fold belt. The spatial and temporal variations of the incision rates along these rivers were estimated from the geomorphological mapping of the Quaternary sediments, the geometry and the dating of the terraces. Eleven terraces levels were identified in Albania from 68 geochronological ages already published or acquired for this work. The five lower terraces of the four studied rivers are well dated (10 new and 23 already published ages). These terraces are younger than $30 \mathrm{ka}$ and their remnants are numerous. Their restoration allows estimating the regional trend of incision rate and the identification of local shifts. We argue that these shifts are linked to the active tectonics when they coincide with the faults already mapped by previous authors. Vertical slip rates for eight active faults in southern Albania are thus estimated for the last 19 $k a$ and vary from $\sim 0.1$ to $\sim 2 \mathrm{~mm} / \mathrm{a}$. The Lushnje Tepelene Thrust, that extends more than 120 kilometers, has a throw rate that varies from 0.2 to $0.8 \mathrm{~mm} / \mathrm{a}$, whereas the active faults of the extensional domain are segmented but are very active, with throw rates reaching locally $2 \mathrm{~mm} / \mathrm{a}$.
\end{abstract}

\section{Introduction}

Albania is one of the most seismically active countries in Europe with damage intensities reaching degree IX of MSK-64 scale. The strongest historical earthquakes occurred along three well-defined seismic belts [Aliaj 1988, Muço 1998, Sulstarova et al. 2003, Kiratzi 2011]: a) The Ionian-Adriatic coastal earthquake belt at the western margin of the European plate, which trends NW-SE to NNW-SSE. It is the most seismically active zone in the country and it is characterized by dipslip to oblique-slip compressional thrust faults. b) The Peshkopia-Korca earthquake belt, in the internal Al- banides, which trends NNW-SSE, characterized by normal faults. c) The Elbasan-Dibra transverse belt, which trends NNE-SSW across the former two. This belt is characterized by normal faults (Figure 1).

In these belts, several studies of earthquake focalmechanism solutions, micro-structural slickenslides analysis and geodetic measures have been made [e.g. Sulstarova 1986, Aliaj 1988, Tagari 1993, Muço 1994, Kiratzi 2011, Jouanne et al. 2012]. Therefore a precise characterization of the seismotectonic stress field and its comparison with GPS velocities is available. However, the characterization of the individual activity of the Albanian active faults is poorly known, and no hierarchy is currently proposed for the neotectonic features (Figure 1). One of the means to characterize the activity of faults is to determine their long-term slip rates by studying the offset of morphological markers like alluvial fans, moraines, fluvial and marine terraces [e.g. Carozza and Delcaillau 1999, Vassallo et al. 2005, Mason et al. 2006, Caputo et al. 2008, Wegmann and Pazzaglia 2009, Caputo et al. 2010, Wesnousky et al. 2012].

The Shkumbin, Devoll, Osum and Vjosa rivers, in southern Albania, flow from East to West, crossing several active faults (Figures 1, 2), and are characterized by the formation of numerous Quaternary terraces [Melo 1961, Prifti 1981]. The morphological mapping of these fluvial terraces (Figure 2; Supplementary data A at http: / / hdl.handle.net/2122/8875), combined with new and published geochronological data (Table 1) [Lewin et al. 1991, Hamlin et al. 2000, Woodward et al. 2001, Koçi 2007, Woodward et al. 2008, Carcaillet et al. 2009], are used in order to reconstruct the spatial and temporal variation of fluvial incision along these rivers. The 
regional trend of incision is related to regional uplift whereas local shifts are interpreted in terms of vertical motion along active faults.

The aim of this paper is to compare the pattern of the incision rate with the existing active tectonic map in order to detect the most active faults and quantify their vertical slip rates.

\section{Geological setting}

Albania is located on the central part of the Dinaric-Albanic-Hellenic Alpine fold belt, which was thrusted westward over the Adriatic foreland during the Alpine orogeny [Sorel et al. 1992]. The Albanian mountains are traditionally divided in Internal and External Albanides (Figure 1). The Internal Albanides display a relatively simple linear geometry and consist partly of ophiolites (i.e. The Mirdita zone). The External Albanides are divided in three thrust zones that are, from East to West, the Krasta-Cukali zone, the Kruja zone and the Ionian zone. All of these zones are characterized by carbonate deposition in syn-rift and post-rift settings, cov- ered by flysch deposits [Robertson and Shallo 2000, Niewland et al. 2001, Roure et al. 2004] (Figure 2).

The geodynamic context is characterized by the subduction of the Adriatic plate beneath the foreland domain. This produces contrasting relief with a flexural basin filled with Plio-Quaternary deposits, forming a flat coastal plain in the foreland [Roure et al. 2004], a thin skinned fold and thrust belt in the midland [Carminati et al. 2004] and a synorogenic NeogeneQuaternary graben system in the hinterland that crosscuts the previous thrust system [Aliaj 1991].

Neotectonics stress field has been studied via micro-structural analysis of slicken-slides [Aliaj 1988, Tagari 1993] and earthquake focal-mechanism solutions [Sulstarova 1986, Muço 1994], which were compared with GPS velocities [Jouanne et al. 2012]. In the external domain, the average axis of compression is oriented $\mathrm{N} 45^{\circ}$, whereas in the internal domain the average axis of extension varies from $\mathrm{N} 90^{\circ}$ close to the Ohrid and Prespa lakes to $\mathrm{N} 160^{\circ}$ at the southern end of the Ersekë basins (Figure 1) [Sulstarova 1986, Aliaj 1988,

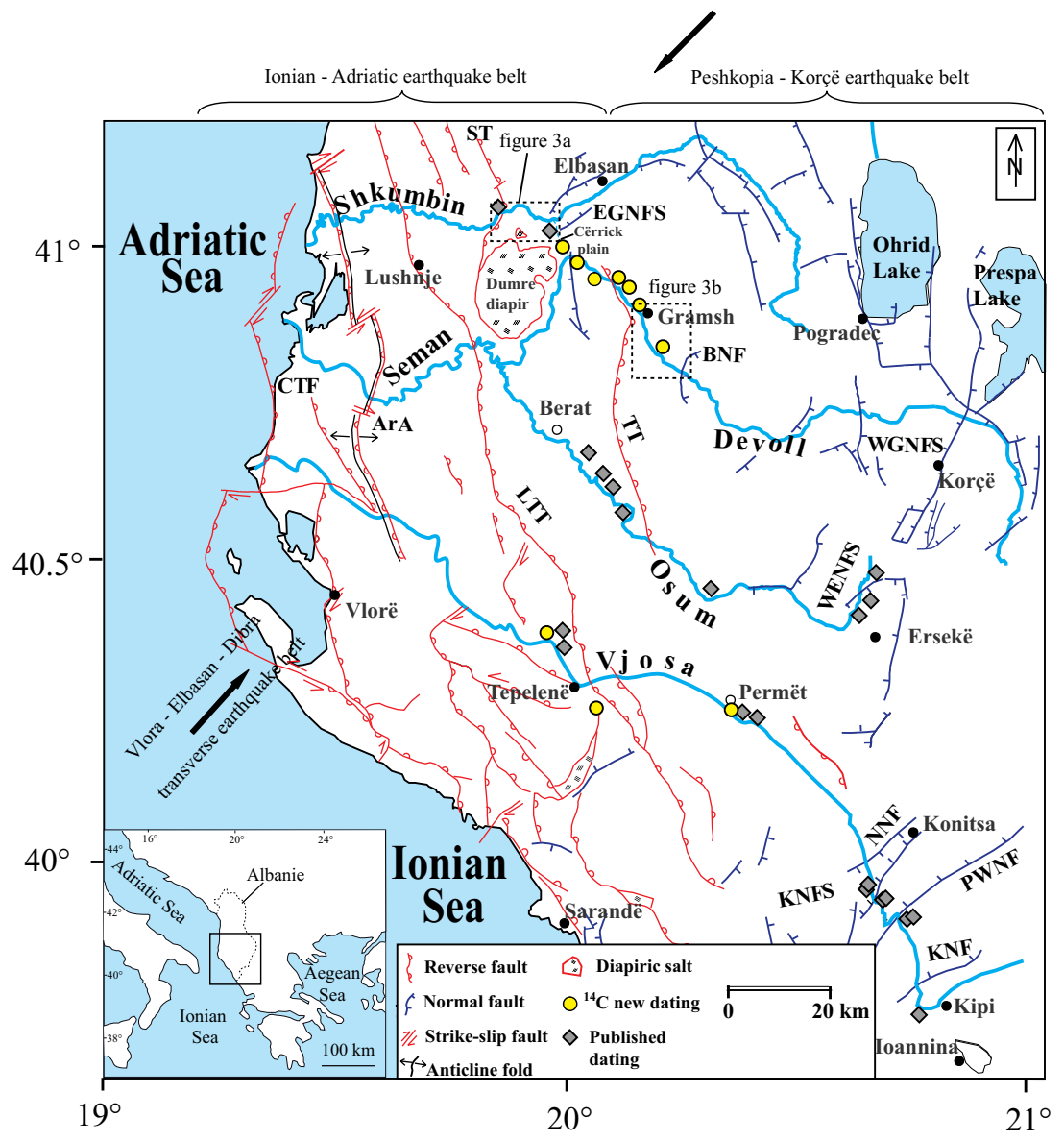

Figure 1. Neo-tectonic map of the Albania and northwestern Greece (modified from Aliaj et al. [1996, 2000] and Carcaillet et al. [2009]). Dark grey diamond indicate published data [Lewin et al. 1991, Hamlin et al. 2000, Woodward et al. 2001, Koçi 2007, Carcaillet et al. 2009] and yellow circles indicate data computed in the present study. Fault types are described in the picture caption. The location of Figure $3 \mathrm{a}, \mathrm{b}$ is shown in the map. (CTF) Coastal Thrust Fault; (ArA) Ardenica Anticline; (LTT) Lushnje - Tepelenë Thrust; (ST) Shkumbin Trust; (TT) Tomorrica Thrust; (BNF) Bulcar Normal Fault; (EG) Elbasan Graben Normal Fault System; (NNF) Nerotrivi Normal Fault; (KNFS) Konitsa Normal Fault System; (PWNF) Papingo West Normal Fault; (KNF) Kipi Normal Fault; (WGNFS) West Graben Normal Fault System; (WENFS) West Ersekë Normal Fault System. These abbreviations are kept unchaged for all figures and text. 


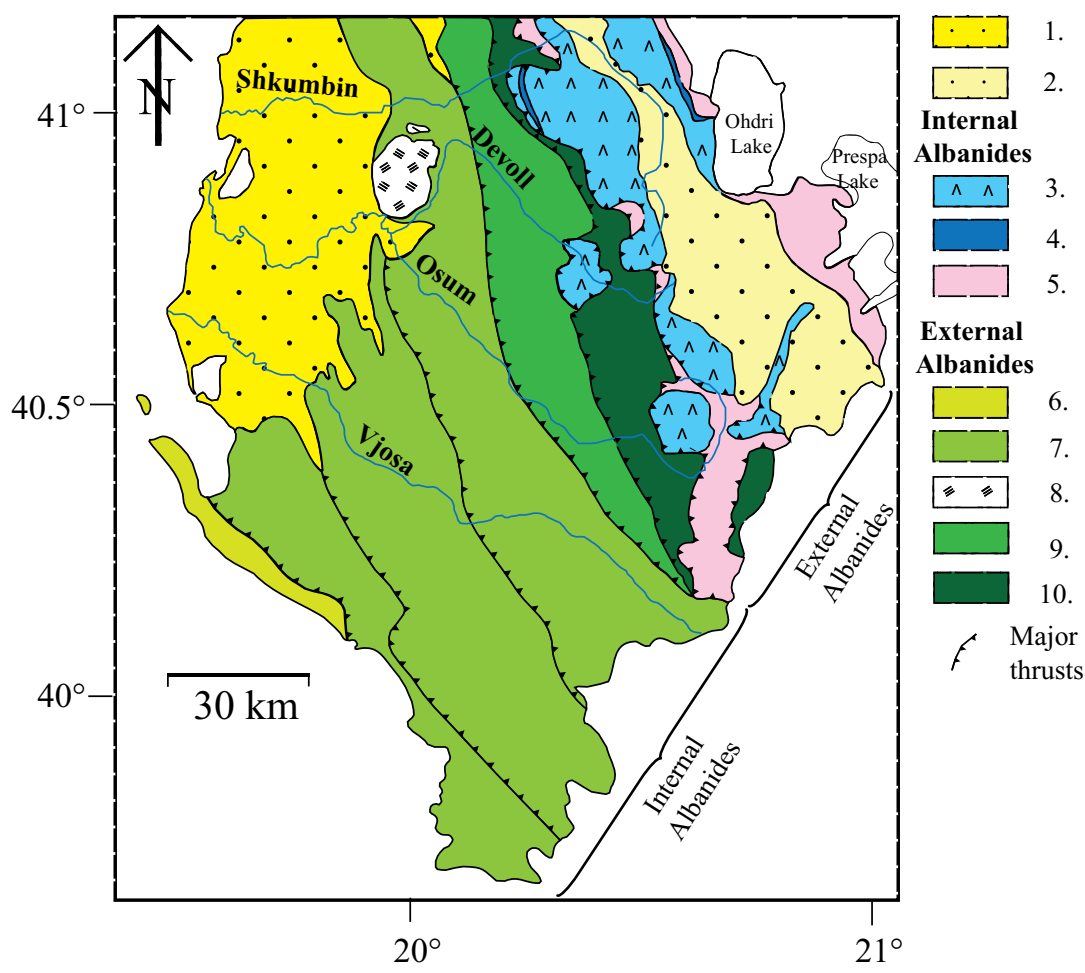

Figure 2. Simplified geologic map of Albania showing main tectonostratigraphic units (modified from Robertson and Shallo [2000], SHGJSH [2003] and Muceku et al. [2008]). Map legende: 1. Periadriatic depression (Neogene - Quaternary siliciclastic sediments); 2. Neogene - Quaternary graben system (Neogene - Quaternary siliciclastic sediments) 3. Mirdita (Jurassic ophiolites); 4. Rubiku (Triassic shallow water carbonates); 5. Korabi (Triassic - Jurassic ophiolitic melange/ flysch/ debris flow); 6. Sazani (Triassic to Paleogene platform carbonates); 7. Ionian (Triassic to Paleogene platform and pelagic carbonates covered by Oligocene to Miocene flysch); 8. Ionian (Triassic evaporites). 9. Kruja (Mesozoic platform carbonates covered by Oligocene-Miocene); 10. Krasta-Cukali (Mesozoic platform carbonates covered by Cretaceous to Eocene flysch).

Jouanne et al. 2012].

The study area is tectonically active and produces both permanent microseismicity and stronger historical earthquakes reaching IX Ms [Aliaj 2000, Sulstarova et al. 2000, 2003]. This seismicity is associated with the uplift of the Albanides mountain range [Aliaj 2000]. This uplift corresponds to a positive vertical movement of the Albanides with respect to the Adriatic-Ionian sea level. This leads to vertical incision by rivers draining the range, and together with Quaternary climatic variation cause the formation of river terraces along their paths.

This study is focused on the structures crossed by Shkumbin, Devoll, Osum and Vjosa rivers, which are four of the six main rivers of Albania. They flow from the SE to the NW, crossing all the structural domains of the internal and external Albanides and most of the currently active structures.

The mapping of active faults has began in 1920 [Fourcart 1921] and numerous active faults were mapped by the Albanian geologists between 1948 and 2000 [e.g. Aliaj 1988, 1991, Aliaj et al. 1996]. The NATO project no. 972342 Seismotectonic and Seismic Albania Hazard Assessment in Albania 1998-2003 compiled all these studies in a seismotectonic map at scale 1:500,000 (Figure 1) and a more than 1,000 pages report [Aliaj et al. 2000, summarized by Aliaj 2000, 2004]. The geological evidences in the field allowed distinguishing three tec- tonics phases: Middle Pleistocene to Holocene, Pliocene to lower Pleistocene and pre-Pliocene to Pliocene. This map is now used as a base for tectonic and seismogenic models of this part of the Adriatic basin (e.g. Copley et al. [2009], Basili et al. [2013] - within EU-FP7 project Seismic Hazard Harmonization in Europe, SHARE). Nonetheless, this map does not give a hierarchy of the faults and all the pre-Pliocene faults are not necessarily still active. Furthermore the Aliaj et al. [2000] work is geographically restricted to the Albanian territory.

In our study, the following structures are analysed (Figure 1):

1) a large extensional system located in eastern Albania, frequently considered as a half graben with a major NNE-oriented fault that dips towards the East [e.g. Dumurdzanov et al. 2005, Fouache et al. 2010a, Kastelic et al. 2012]; however several faults affecting its hanging wall have been documented from the initial mapping of Fourcart [1921], from the work of Tagari et al. [1993], and modified from our personal field work [Carcaillet et al. 2009]. This system is separated in the following in the West Graben Normal Fault System (WGNFS) and West Ersekë Normal Fault System (WENFS);

2) a transverse extensional fault system located in the central part of Albania, mainly oriented NE-SW. The study of this system is based on the work of Melo [1961], Aliaj [1999] and Sulstarova et al. [2000], and it is 


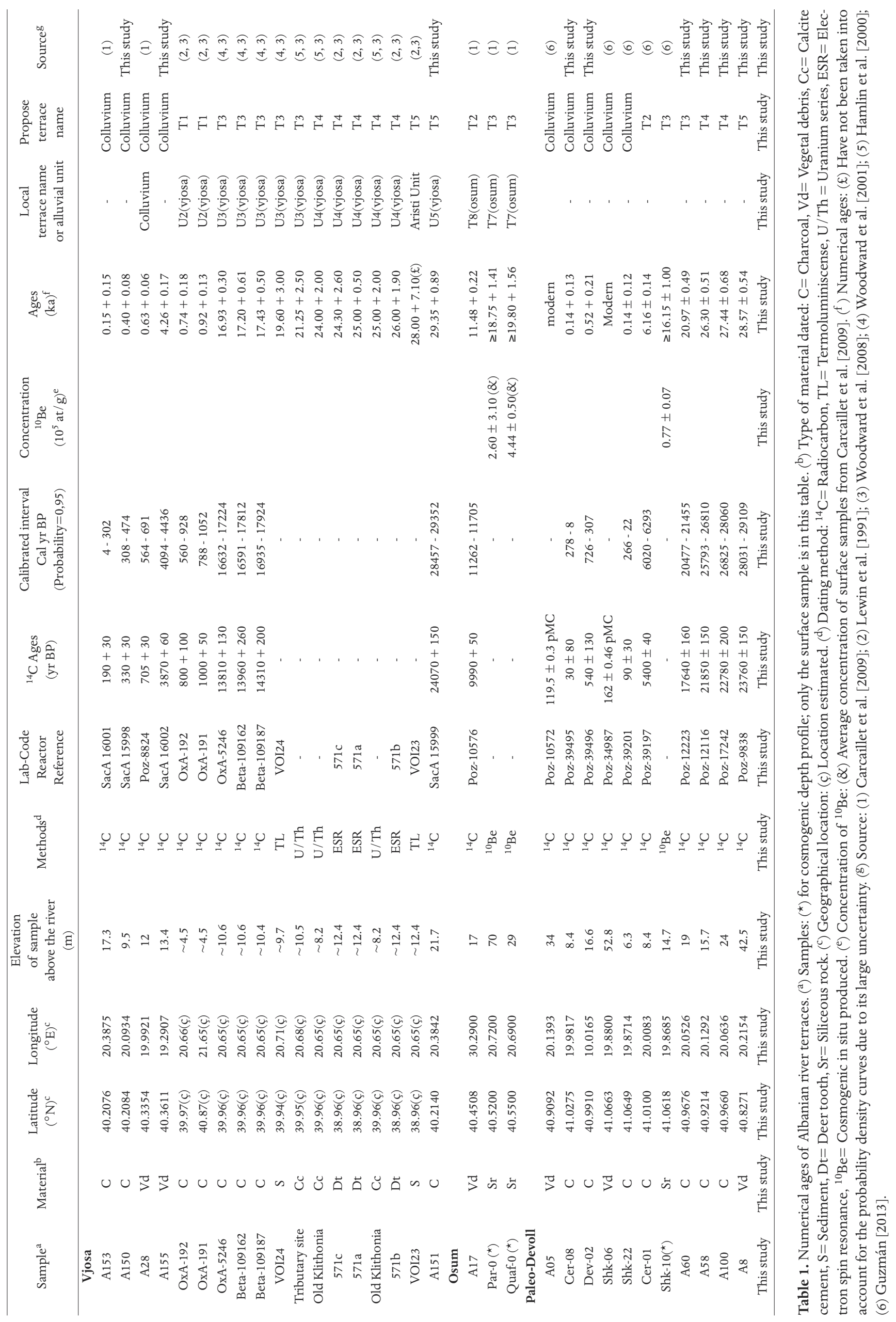


named in the following Elbasan Graben Normal Fault System (EGNFS);

3) two compressional faults located from the central to southern part of Albania, roughly trending NNE-SSW. These faults are named in the following the Tomorrica Thrust (TT) and Lushnje-Tepelenë Thrust (LTT). They are major geological contacts [SHGJSH 2003], and represent the thrust at the footwall of the Kruja zone and at the footwall of the Berati belt (within Ionian zone), respectively. These thrusts are considered as locally reactivated by Aliaj et al. [2000];

4) another compressional fault also located in the central part of Albania between the TT and LTT, with a main orientation of NNE-SSW. The study of this fault is based on the work of Melo [1961] and Aliaj et al. [2000], and it is named in the following Shkumbin Thrust (ST);

5) two other compressional structures also oriented NNE-SSW and located in western Albania, have been studied in details with hydrocarbon [Aliaj 1971, 2006] and archaeological objectives [Fouache et al. 2010b]. These structures are respectively named Ardenica Anticline (ArA) and Coastal Thrust Fault (CTF);

6) for the active tectonics of northwestern Greece, the work of Waters [1993] is used to define the cartography of Kipi Normal Fault (KNF), Papingo West Normal Fault (PWNF), Konitsa Normal Fault System (KNFS) and Nerotrivi Normal Fault (NNF);

7) the Bulcar Normal Fault (BNF) is an active fault that reactivates the base of the Mirdita zone in the middle reaches of the Devoll river. It has been detected during our field work from faulting and slicken-slide that affect the alluvial deposits of the terrace T7 (Figure 4).

\section{Methods}

Field observations, topographic maps at 1:25,000 scale [Institutin Topografik te Ushtrise Tirane 19591990], satellite imagery, and a 30-m digital elevation model based on the Shuttle Radar Topographic Mission (SRTM) were used to identify and characterize fluvial terraces in the study rivers. Alluvial deposits thicknesses and elevations of the terraces above the present riverbed were measured using a measuring tape and a laser range distancemeter (vertical precision $\pm 0.5 \mathrm{~m}$ ).

The remnants of the river terraces found along the rivers were correlated from the map relationship (Figure 3; Supplementary data A at http:/ / hdl.handle.net/ $2122 / 8875)$ and through the sedimentological and stratigraphic analysis of their alluvial deposit characteristics.

Figure 4 (right). Fault plane of the Burcal Normal Fault through the alluvial deposit of terrace T7 at the middle reaches of the Devoll river. See Figure 1 for the location of the fault.

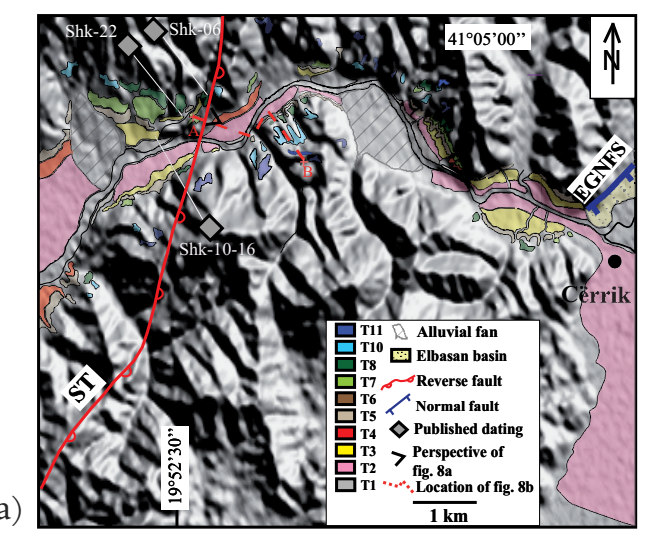

b)

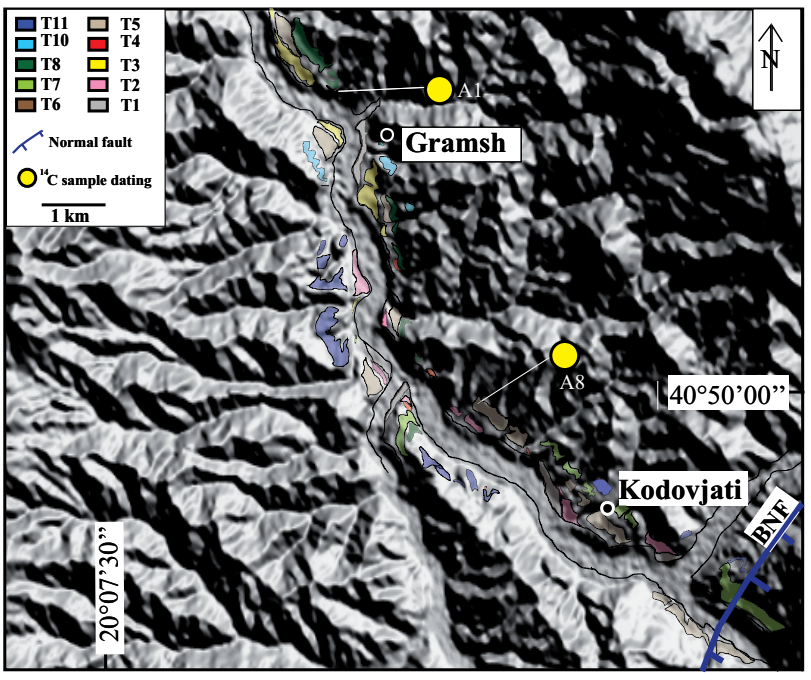

Figure 3. Geomorphic map extracts of the Shkumbin (a) and Devoll (b) rivers. Samples and geographical location mentioned in the text are shown. The location of Figure 8 is also shown. See Supplementary data A (at http: / hdl.handle.net/2122/8875) for a regional geomorphic map.

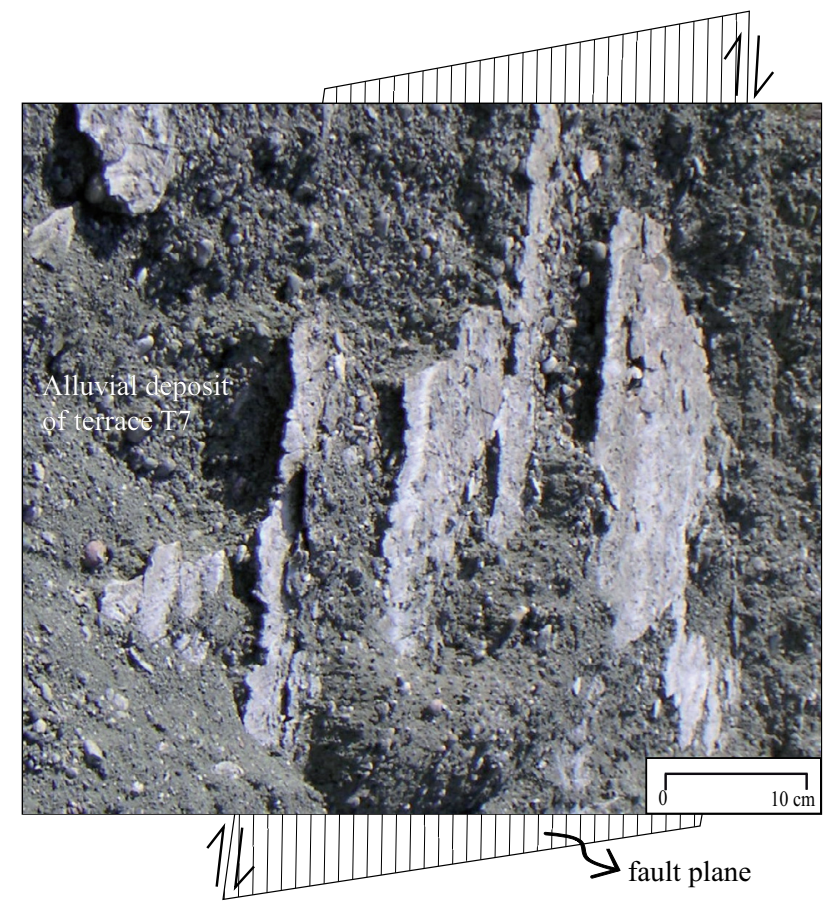



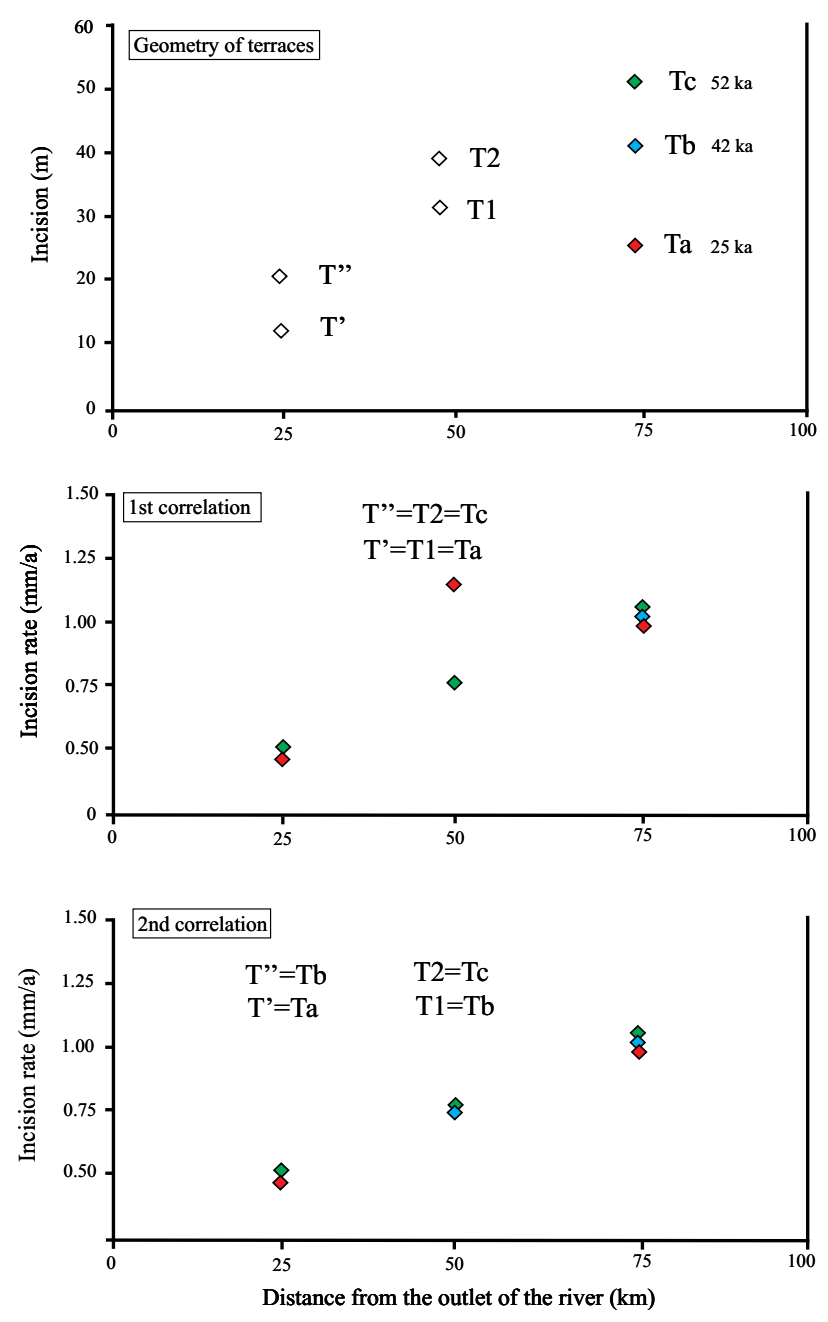

Figure 5. Idealized correlation of remnants of river terraces between distant reaches of the river using an incision rate diagram. In this idealized example, the river does not cross active faults, homogeneous bedrock is present along the river valley and the incision rates at the different reaches have been different but constant over the analyzed time. (a) Geometry of terraces. Different numbers of terraces are identified along the river valley. Terrace ages are provided for the three terraces located at $\mathrm{km} 75$. (b) In the first correlation, terraces located at $\mathrm{km} 25$ and 50 are correlated with the highest and lowest terraces of $\mathrm{km} 75$. Anomalous value for the incision rate of the terrace $\mathrm{T} 2$ located at $\mathrm{km} 50$ allow identifying that the correlation proposed is probably erroneous. (c) In the second correlation, terraces located at $\mathrm{km} 25$ are correlated with the highest and lowest terraces located at $\mathrm{km} 75$, while terraces located at $\mathrm{km} 50$ are correlated with the intermediate and the lowest terraces located at $\mathrm{km} 75$. The similarities between the values of the incision rates in the diferent reaches indicate that the correlation proposed is coherent.

This fieldwork correlation was reinforced by morphogeochronological data, obtained from data previously published by Lewin et al. [1991], Hamlin et al. [2000], Woodward et al. [2001], Carcaillet et al. [2009], as well as radiocarbon $\left({ }^{14} \mathrm{C}\right)$ dating performed specifically for this study (Table 1). The incision rates were determined by calculating the ratio between the heights of the terraces above the river and the age of the terraces [Burbank and Anderson 2001, Pazzaglia and Brandon 2001, Caputo et al. 2008, Weggman and Pazzaglia 2009]. Moreover, our
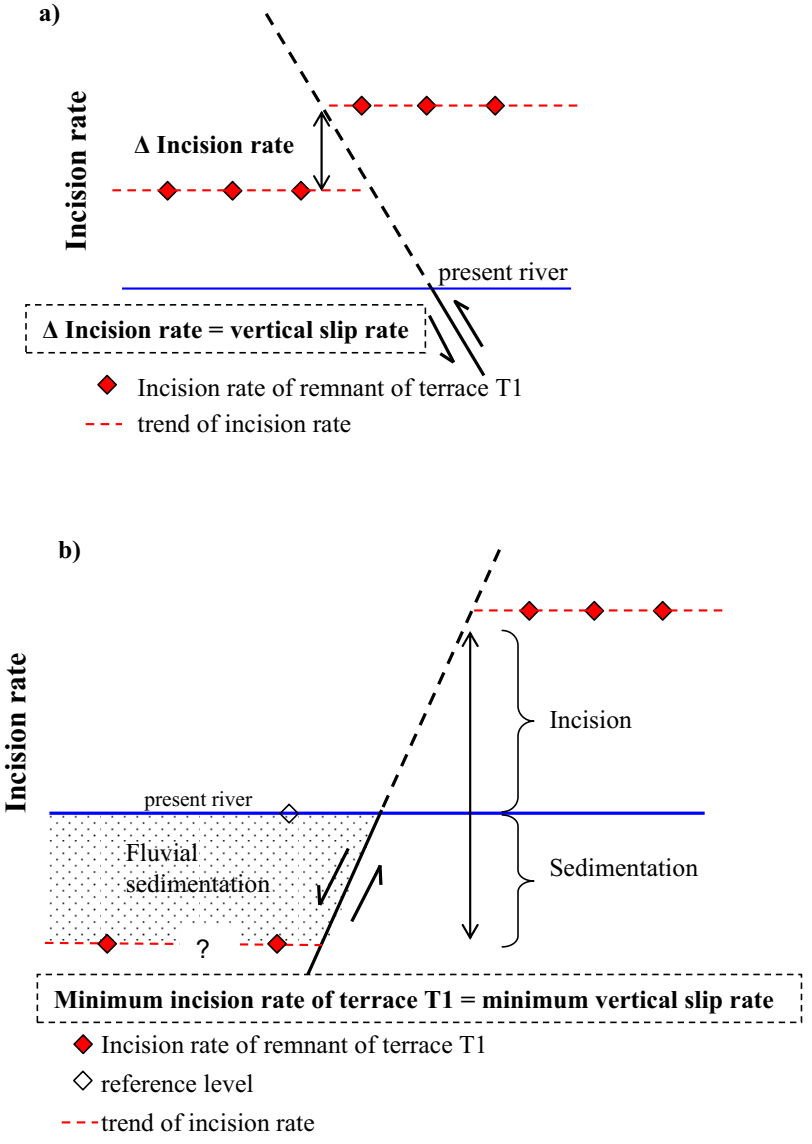

Figure 6. Definition of fluvial incision and vertical slip rate in a context of: (a) without sedimentation; (b) with sedimentation in the footwall block. In case b, the level of the present river is taken as a reference level in the footwall block. The incision and the vertical slip rates estimated are thus minimal.

mapping correlation takes also into account the encased pattern of several terraces. In fact, the use of a diagram representing incision rate rather than terraces heights above the riverbed, allows a further checking for terraces correlation (Figure 5). Distant and solitary terraces are found in the upper reaches of the Devoll (between $\mathrm{km} 110$ and 145), in the middle reaches of the Osum (around $\mathrm{km} \mathrm{141)}$ and in the lower reaches of the Vjoja (between $\mathrm{km} 70$ to 110 and $\mathrm{km} 120$ to 145), and their correlation is not clear. In other cases, the available dating for the upper and lower reaches allowed the correlation of the terraces between distant reaches.

Vertical slip rates were deduced from the local shifts in the average regional trends of the incision rates (Figure 6). This approach avoids the possible effect produced by the roughness of the terrace surfaces. In most cases the terraces are not preserved above the fault trajectory, preventing the direct observation of fault scarps [Avouac 1993], and direct estimation of slip rate. We thus used the altitude of the closest terrace remnants and the general trend of the incision rate in order to estimate the rate. Where rivers cross an aggrading domain, we are unable to know the terrace reference level within the sedimentation domain. In these cases, a minimum ver- 


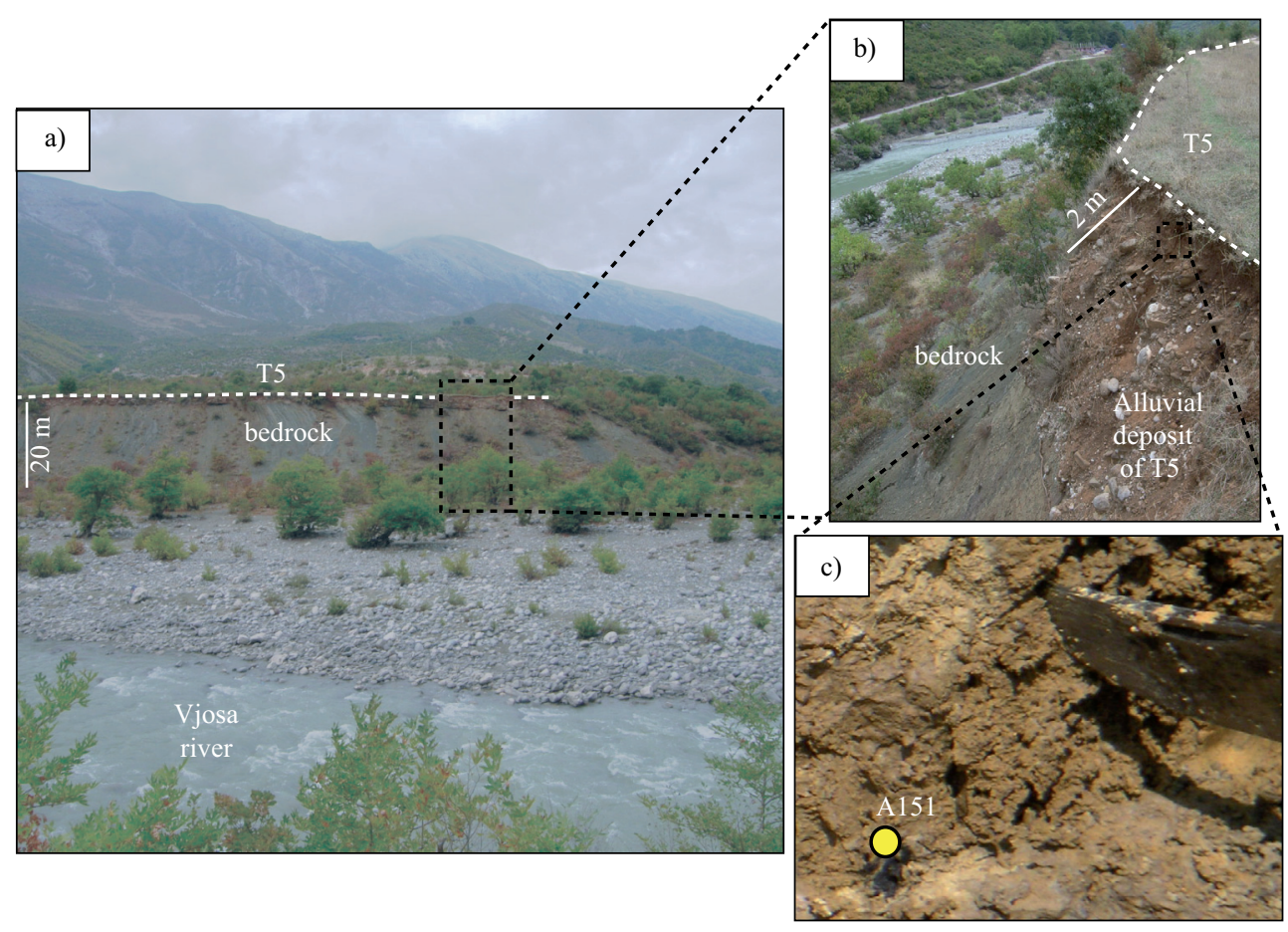

Figure 7. Example of a thin strath terrace above the Vjosa river. (a) General view: the top of the terrace is $22 \mathrm{~m}$ above the low flow of the river. (b) View of the alluvial deposit located above the strath surface. The deposit is around $2 \mathrm{~m}$ thick. It is constituted by gravels and pebbles embedded in a clay and silt matrix. Radiocarbon sample was taken close to the top of the terrace. (c) View of a sampled organic material (sample A151, in Table 1) that gives an age of abandonment of $29.35 \pm 0.89$ cal ka BP ka for this terrace (terrace T5).

tical slip rate was estimated considering the height of the present river as a reference level (Figure $6 \mathrm{~b}$ ).

\section{Age of terraces}

A succession of at least eleven regional terraces has been identified in Albanian rivers [Aliaj et al. 2000, Woodward et al. 2001, 2008, Carcaillet et al. 2009, Guzmán 2013]. Even though not all theses terraces are found along each individual river, the Shkumbin and Devoll rivers exhibit a quite complete record (ten terraces). Most of the high terraces are thick fill terraces (8-30 m-thick) whereas the lower terraces are thin strath terraces (1-5 m-thick) (Figures 3, 7, 8).

Sixty-eight numerical ages are available for all the Albanian terraces dated along six rivers. There is a lack of numerical ages for the highest identified terraces. By contrast, fifty-four datings allow constraining the ages of the eight lower terraces. Ten new numerical ages are provided in this study and forty-four are provided by previous studies (in order to simplify the presentation of ages, in this study, we only show the ages for the terraces used for the incision rate reconstruction (T5 to T1), for all dating see Supplementary data B at http:/ / hdl.handle.net/2122/8875) [Lewin et al. 1991, Hamlin et al. 2000, Woodward et al. 2001, Koçi 2007, Carcaillet et al. 2009, Guzmán 2013]. These ages result from analytical measurements coming from different parts of the river catchments, from different rivers or from different dating methods (i.e. ${ }^{14} \mathrm{C},{ }^{10} \mathrm{Be}$, $\mathrm{U}$ series $(\mathrm{U} / \mathrm{Th})$, electron spin resonance (ESR), thermoluminescense (TL); Table 1).

According to the strategy used by Carcaillet et al. [2009] and Guzmán [2013], ${ }^{10} \mathrm{Be}$ ages used in this study represent the surface exposure ages of the terraces [Gosse and Phillips 2001]. ${ }^{14} \mathrm{C}$ ages and the others ages achieved in previous studies, using others methods and strategies (U/Th, ESR, TL) [Lewin et al. 1991, Woodward et al. 2001, 2008], represent the timing of deposition or formation of a particular sediment or material within the alluvial deposit of the terrace [Stratton Noller et al. 2000]. ${ }^{14} \mathrm{C}$ samples taken in this study, and also the material used in previous dating studies (e.g. calcite cement, deer tooth) were taken from the sediments that correspond to the ultimate phase of river aggradation (Figure 7). These ages thus represent a maximum age of abandonment of the river terrace. Despite the different meaning of the samples dated, a good agreement between most of the ages analysed in this study, either new or published, allow suggesting that the process of formation of each terrace in Albania occurs in a maximum time span of few thousand years (Figure 9). Thus, considering the uncertainties on the ages and the aim of this study, we assumed that the formation of each Albanian terrace is synchronous at the spatial scale of the river catchments.

The age of each terrace is determined from the normal distribution of individual calibrated ages and their associated two sigma errors (95\%) using the cu- 
$\mathrm{E}$
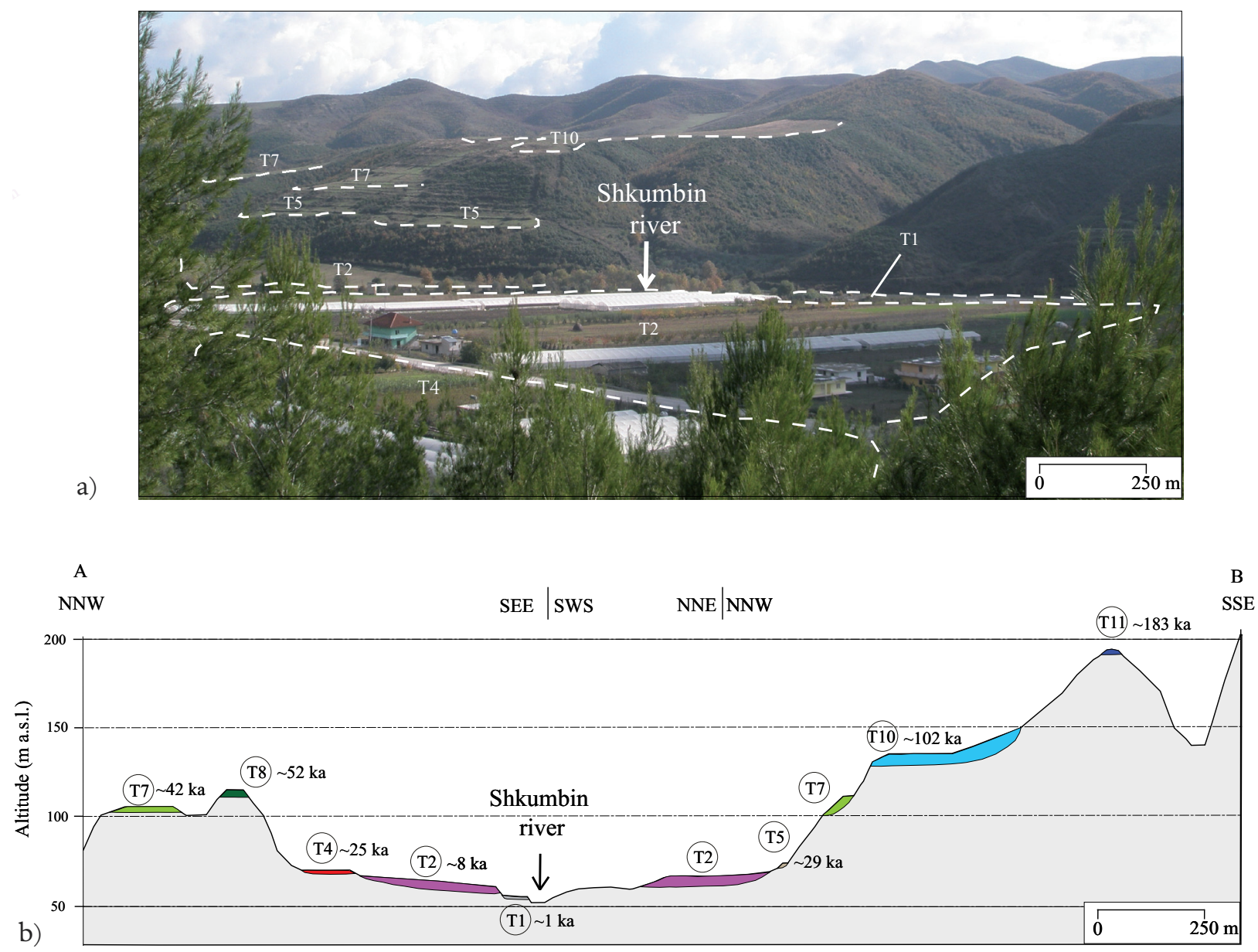

Figure 8. (a) Panoramic view of the lower Paleo-Devoll river showing the location of terraces. The numbers refer to the nomenclature proposed in Guzmán [2013]. The present Shkumbin river is shown in the figure. (b) Cross section through the encased terraces in the lower PaleoDevoll. The ages of the terraces from previous studies are indicated [Lewin et al. 1991, Hamlin et al. 2000, Woodward et al. 2001, Koçi 2007, Carcaillet et al. 2009, Guzmán 2013].

mulative probability command within OxCal 4.1 calibration program [Ramsey 2009]. The result is a probability density plot of all the ages (Figure 9), a representation already used in similar studies of large set of dates [Meyer et al. 1995, Wegmann and Pazzaglia $2002,2009]$. This gives six high probability ages for the period between 60 to $12 \mathrm{ka}: 51.8 \pm 2.4 \mathrm{ka} ; 41.8 \pm 0.5 \mathrm{ka}$; $34.8 \pm 3.2 \mathrm{ka} ; 29.4 \pm 0.8 \mathrm{ka} ; 24.8 \pm 1.8 \mathrm{ka} ; 18.7 \pm 2.1 \mathrm{ka}$ from T8 to T3. All these ages are coherent with climatic river terrace ages documented along the wide Mediterranean domain [e.g. Fuller et al. 1998, Macklin et al. 2002, Wegmann and Pazzaglia 2009] and dicussed in detail by Guzmán et al. [2011] and Guzmán [2013]. Available datings for terrace T2 are more scattered. Nevertheless all of them are close to a global cold climatic event at $8.2 \mathrm{ka}$ identified by Kallel et al. [2000] in the eastern Mediterranean and in the sediment of the Prespa lake located in the West border of Albania [Wagner et al. 2010]. Hence, we argue that the age of abandonment of terrace T2 is around $8.2 \mathrm{ka}$. T1 is the lower terrace and in some localities the base of the alluvial deposit that composed this terrace is lower than the flow channel. Thus, we considered that this terrace could still be affected by the river dynamics. The most probable ages discussed here are combined with our mapping correlation, to estimate the incision rates for all terrace remnants along the Shkumbin, Devoll, Osum and Vjosa rivers.

\section{Morphological analysis}

\subsection{Shkumbin and Devoll system}

These two rivers are located in the central part of Albania (Figures 1, 2). Nowadays, the Shkumbin and Devoll rivers flow in two different catchments. However geomorphologic and sedimentologic evidence around the Cërrik plain [Melo 1961, Guzmán et al. 2011, Guzman 2013] suggest that the downstream part of the Shkumbin corresponds to the Paleo-Devoll river (Figure 1). This divergence occurred around $\sim 6 \mathrm{ka}$ [Guzman 2013]. As a consequence, terraces developed along the upper and middle Devoll and lower Shkumbin can be 


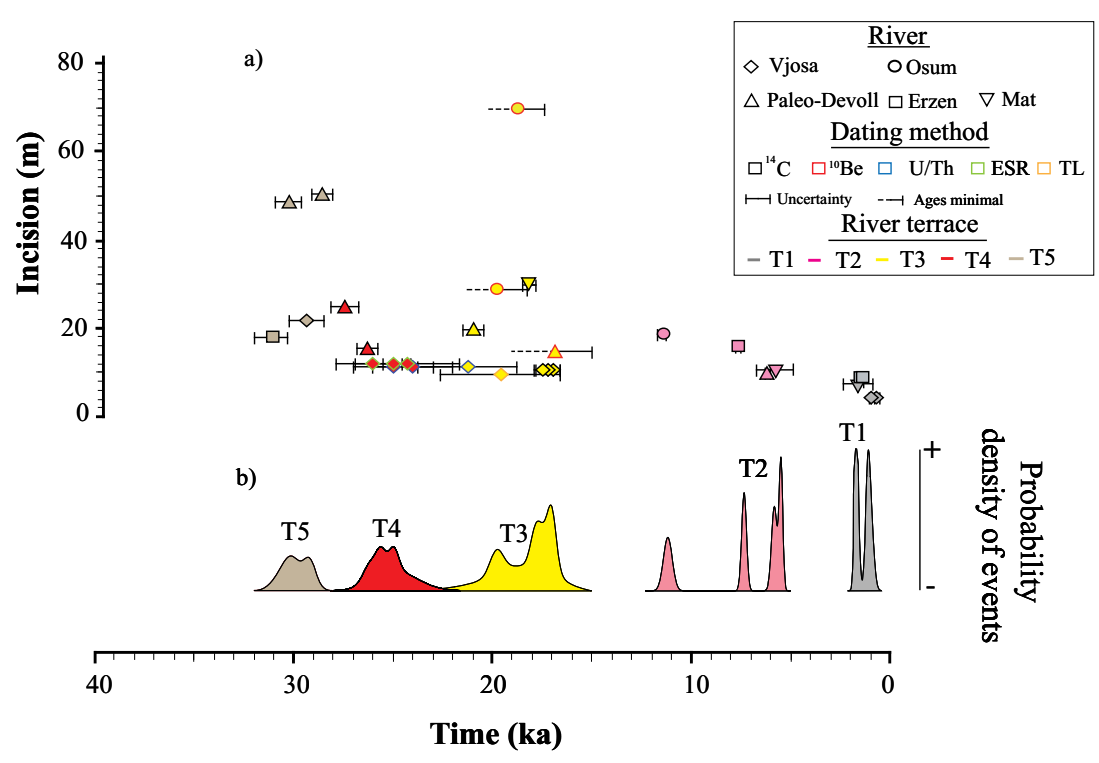

Figure 9. Compilation of Albanian terraces ages for the last $30 \mathrm{ka}$ (Table 1). (a) Plot of incision versus terraces ages. Each terrace is represented by a symbol related to the river. The colour of the border of the symbol corresponds to the dating method while the fill corresponds to the terrace level. (b) Probability density curves of age of terraces. The probability curves was produced by calculating calendar ages and their two sigma (95\%) analytical errors and then summing the normal probabilities distribution defined by individual ages using the OxCal program version 4.1 [Ramsey 2009].

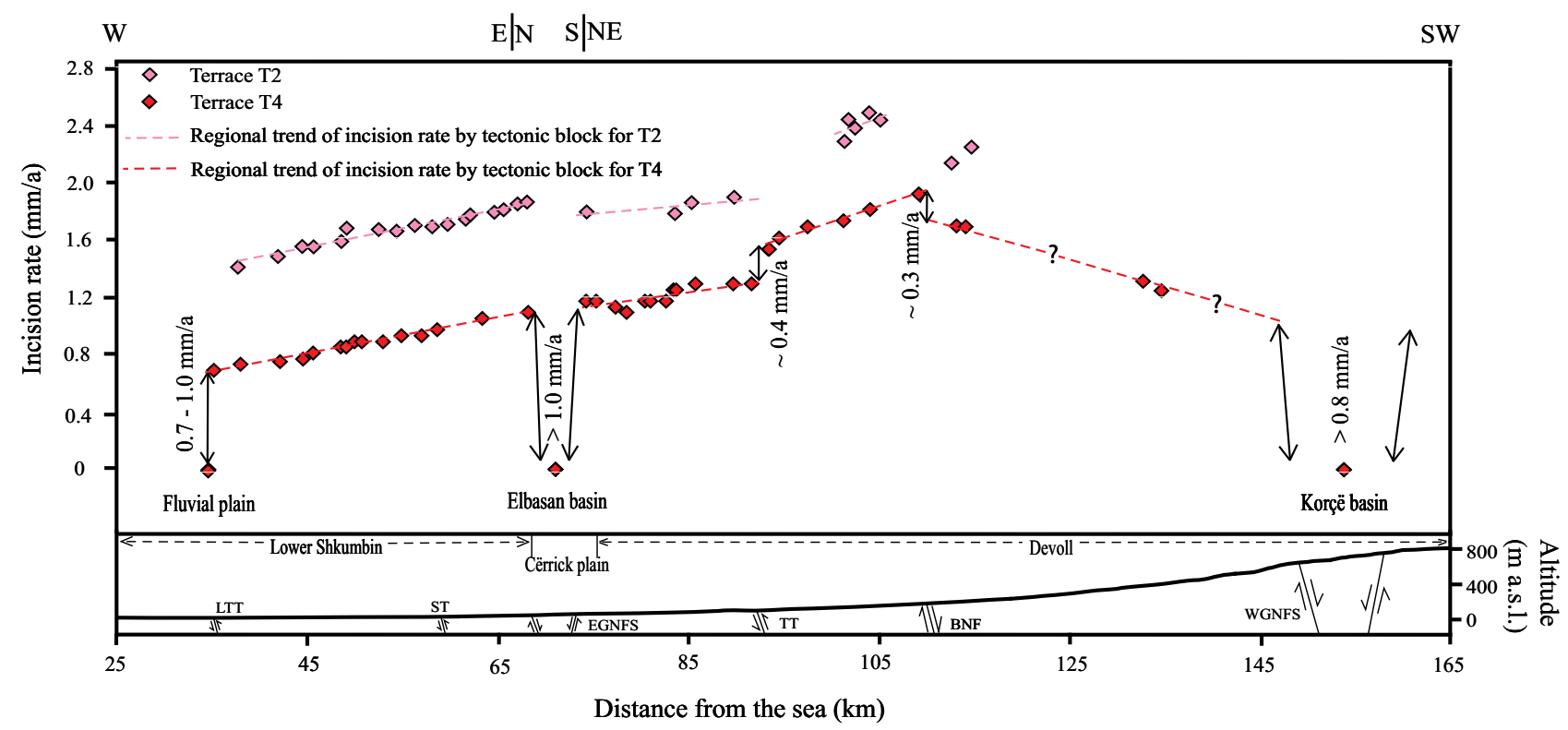

Figure 10. Evolution of the incision rate along the combined river profile of the lower Shkumbin and Devoll (Paleo-Devoll river). Left axis is the calculated incision rate; right axis is the elevation of the present-day river bed. Colour of the diamonds refers to the different terraces units. Into the lower box, appear the present-day river profile, on which are indicated the active faults. In the sedimentation zones (Fluvial plain, Elbasan and Korçë basins) the correlative deposits of terrace T4 are located in the present river-bed. In the river profile are located the Lushnje - Tepelenë Thrust (LTT),Shkumbin Trust (ST), Tomorrica Thrust (TT), the Burcal Normal Fault (BNF) and the West Graben Normal Fault System (WGNFS).

analysed together along the Paleo-Devoll profile.

The dominance of sedimentation against incision along the last $25 \mathrm{~km}$ (close to the sea) of the Paleo-Devoll [Fouache et al. 2010b] prevents the preservation of terraces in this area. On the other hand, ten river terraces were identified along the section located between 25 and $165 \mathrm{~km}$ from the Adriatic Sea. Among these, remnants of the terraces $\mathrm{T} 4$ and $\mathrm{T} 2$, dated respectively around $\sim 25$ and $8.2 \mathrm{ka}$, are the best preserved and are nearly continuous along almost all the section (Figure 10). Hence, the geometries of these two terraces were used for the study of fault activity.

In Figure 10, we plotted together: 1) the modern river profile, 2) the Quaternary active faults (adapted from Aliaj et al. [1996, 2000]), 3) the river incision rates estimated for each remnant of terrace and 4) the average regional trend of the incision rates for each tectonic block. This plot shows a regional upstream increment 


\begin{tabular}{|c|c|c|c|c|c|c|}
\hline \multirow[t]{2}{*}{ Structure name } & \multirow[t]{2}{*}{$\begin{array}{l}\text { Acronym } \\
\text { (in text) }\end{array}$} & \multirow[t]{2}{*}{ River } & \multirow[t]{2}{*}{$\begin{array}{l}\text { Vertical slip rate } \\
\qquad(\mathrm{mm} / \mathrm{a})^{\mathrm{a}}\end{array}$} & \multicolumn{3}{|c|}{$\begin{array}{l}\text { Active fault lenght } \\
\qquad(\mathrm{km})\end{array}$} \\
\hline & & & & Aliaj et al. 2000 & Waters 1993 & This study ${ }^{b}$ \\
\hline Coastal Thrust Fault & CTF & Paleo-Seman & $>0.1(1)$ & $\geq 80$ & - & - \\
\hline Ardenica Anticline & ArA & Paleo-Seman & $>0.1(1)$ & - & - & - \\
\hline Lushnje - Tepelenë Thrust & LTT & Paleo-Devoll & $0.7-1.0$ & $\sim 100$ & - & $>120$ \\
\hline Lushnje - Tepelenë Thrust & LTT & Vjosa & $<0.2$ & & - & \\
\hline Tomorica Thrust & TT & Paleo-Devoll & $\sim 0.4$ & $\sim 20$ & - & $\geq 50$ \\
\hline Tomorica Thrust & TT & Osum & $\sim 0.3$ & & - & \\
\hline Elbasan Graben Normal Fault System & EGNFS & Paleo-Devoll & $>1.0$ & $\geq 5$ & - & $\geq 5$ \\
\hline Burcal Normal Fault & $\mathrm{BNF}$ & Paleo-Devoll & $\sim 0.3$ & - & - & $\sim 10$ \\
\hline West Ersekë Normal Fault System & WENFS & Osum & $1.3-2.0$ & $\sim 10$ & - & $>20^{\star}$ \\
\hline West Graben Normal Fault System & WGNFS & Paleo-Devoll & $>0.8$ & $\leq 20$ & - & $>20^{\star}$ \\
\hline Nerotrivi Normal Fault & NNF & Vjosa & $>0.4$ & - & 15 & $\geq 15^{\star}$ \\
\hline Konitsa Normal Fault System & KNFS & Vjosa & $>0.4$ & - & 15 & $\geq 15^{\star}$ \\
\hline
\end{tabular}

Table 2. Vertical slip rate of active structures in Albania, analyzed from the incision of river terraces of Paleo-Devoll, Osum and Vjosa rivers. (a) Vertical slip rate: (1) Fouache et al. [2010b]. (b) Active fault length: $\left(^{\star}\right)$ Length for one segment of the system.

of the incision rate of the two terraces until $\mathrm{km} 112$ of the valley, where the incision rate starts decreasing. However, the number of preserved remnants of terraces $\mathrm{T} 2$ and $\mathrm{T} 4 \mathrm{in}$ this area is limited; therefore the trend of the incision rate in the upper reaches of the river remains uncertain. The river incision rate estimated from $\mathrm{T} 2$ is higher than the incision rate deduced from $\mathrm{T} 4$, a trend already evidenced and discussed by Carcaillet et al. [2009].

Local shifts in the incision rate are identified at $\mathrm{km}$ 35, 68, 73, 92, 110 and 149 of the valley (Figure 10). These shifts are situated close to the emergence of the following faults: LTT, EGNFS, TT, BNF and WGNFS (Figures 1, 9). No lithological changes occur at these points, except at $\mathrm{km} 110$ (Figure 2). Therefore, we argue that the local shifts in the incision rate observed along of the Devoll and Shkumbin rivers are induced by the Quaternary activity of the mentioned faults. Assuming a constant vertical motion of the faults since at least 25 $\mathrm{ka}$, we estimated a vertical slip rate for LTT between 0.7 and $1 \mathrm{~mm} / \mathrm{a}$, for EGNFS $>1 \mathrm{~mm} / \mathrm{a}$, for TT $\sim 0.4$ $\mathrm{mm} / \mathrm{a}$, for BNF $\sim 0.3 \mathrm{~mm} / \mathrm{a}$ and for WGNFS $>0.8$ $\mathrm{mm} / \mathrm{a}$ (Figure 10, Table 2). No local shift in the regional trend of the incision rate is observed close to the emergence of the ST. Hence, either the activity of this fault does not influence the evolution of the river profile or this fault has been inactive since $25 \mathrm{ka}$.

\subsection{Osum river}

This river is located in southern Albania (Figure 1), flows over $160 \mathrm{~km}$, and connects with the Devoll river in the fluvial plain downstream of the city of Berat.
This confluence forms the Seman river, which together with its tributaries forms the longest drainage system of Albania.

In this study, we analyzed the reaches of the Osum river located between 120 and $220 \mathrm{~km}$ from the Adriatic Sea, where the preservation of nine river terraces [Carcaillet et al. 2009] allows the estimation of the effect of faults activity. As for the Shkumbin and Devoll, due to the objectives of the present study, we only present the incision rate of the two most frequently observed terraces developed around $\sim 19$ and $8.2 \mathrm{ka}$ (T3 and T2, respectively) that are presented in Figure 11.

A regional upstream increment in the incision rate for the two terraces is observed. An abrupt local shift in the trend of the incision rate of terrace T3 is identified at $\mathrm{km} 217$ of the valley. Another shift is recognizable from the slope-break in the regional trend of incision rate of the terrace T2. This shift is located between 175 and 192 $\mathrm{km}$ from the Adriatic Sea. A third shift located between 150 and $166 \mathrm{~km}$ is less evident, but it can be identified from the extrapolation of the regional trend of incision rate of terrace T3. The emergence of the TT (at km 164) and WENFS (at km 190 and 217) are located in the zones where these shift are observed (Figure 11). Therefore, we propose that the local shifts in the trend of the incision rate are associated with Quaternary activity of the TT and WENFS. We estimate that at least for the last $19 \mathrm{ka}$ the vertical slip rate of the TT is $\sim 0.3 \mathrm{~mm} / \mathrm{a}$, while it varies between 1.3 and $2 \mathrm{~mm} / \mathrm{a}$ for the West and East segment of WENFS, respectively (Figure 11, Table 1). These last values agree with the estimation $(2.2 \mathrm{~mm} / \mathrm{a})$ done by Carcaillet et al. [2009] for the East segment. 


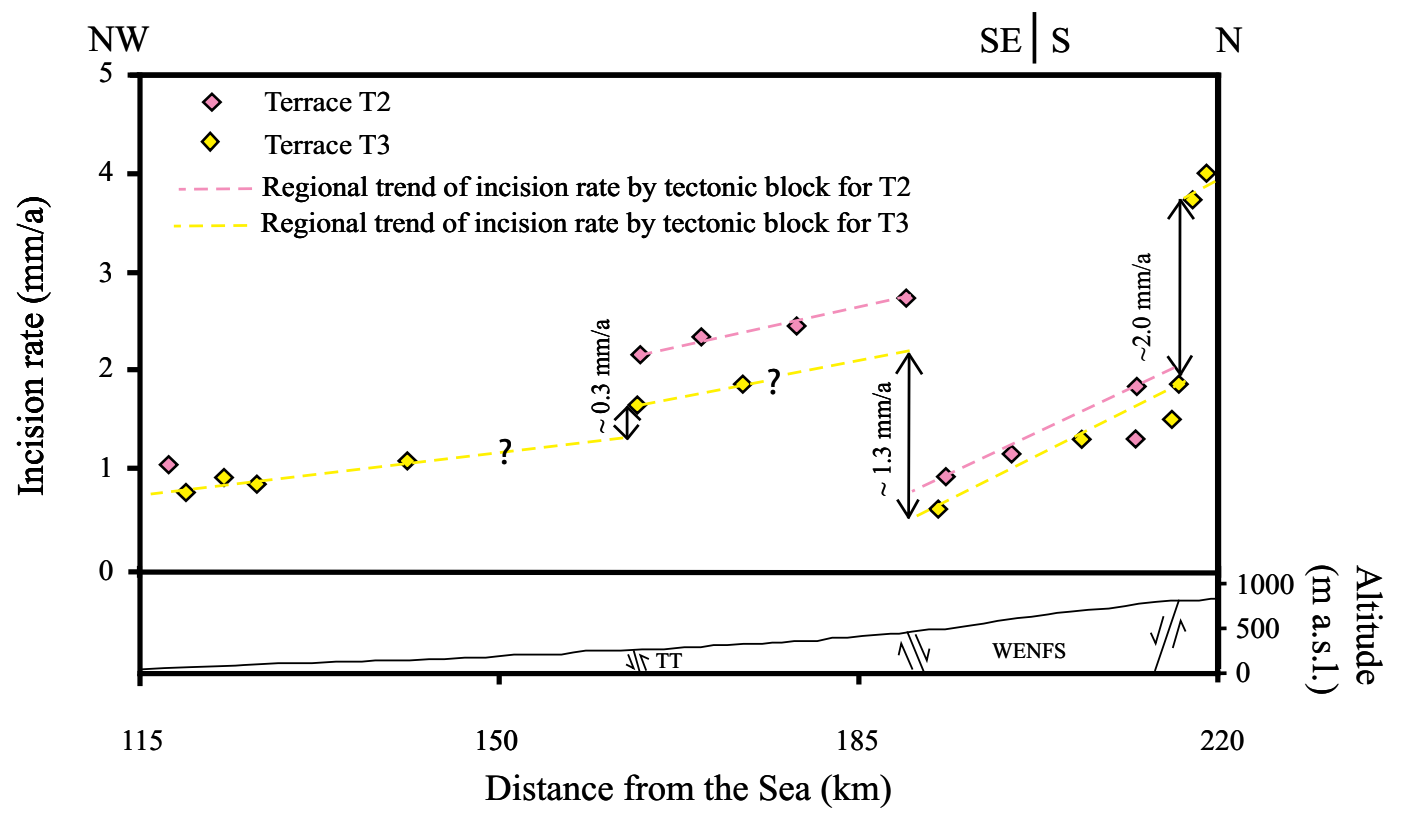

Figure 11. Evolution of the incision rate along the river profile of the Osum. Bold lines represent normal faults belonging to West Ersekë Normal Fault System (WENFS) and Tomorrica Thrust (TT).

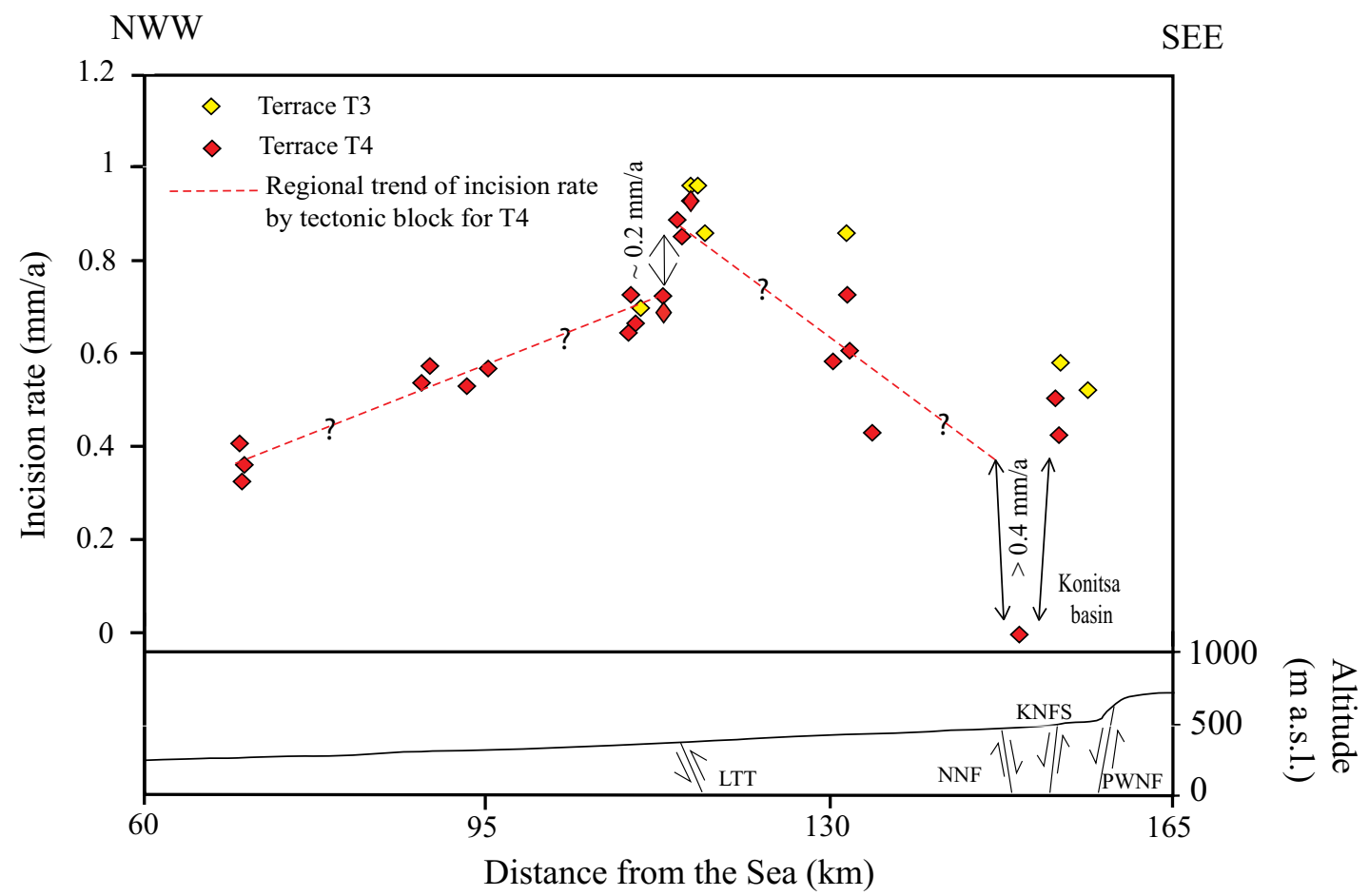

Figure 12. Evolution of the incision rate along the river profile of the Vjosa. In the Konitsa basin the correlative deposit of terrace T4 is located in the present river-bed. In the river profile are located the Lushnje-Tepelenë Thrust (LTT), Nerotrivi Normal fault (NNF), Konitsa Normal Fault System (KNFS) and Papingo West Normal Fault (PWNF).

\subsection{Vjosa river}

The Vjosa river, called Voidomatis in Greece, flows towards NW for around $272 \mathrm{~km}$ from the Greek land to the Adriatic Sea (Figure 1). The Vjosa flows in an atypical catchment in the Mediterranean zone: its upper part was glaciated during the Last Glacial Maximum (LGM) [Clark et al. 2009], as suggested by well-preserved glacial features [Lewin et al. 1991].

Five river terraces for the section of Vjosa located between 60 and $165 \mathrm{~km}$ from the Adriatic Sea were identified (Figure 12). These terraces are located in small reaches and the information about the spatial evolution of the incision rate is limited. However, the continuity of the terraces T4 and T3 between $\mathrm{km} 109$ and 117 allow evaluating the activity of the fault in this zone with a good degree of confidence. A local shift of the incision rate observed at $\mathrm{km} 112$ is probably associated with the Quaternary activity of the LTT. 


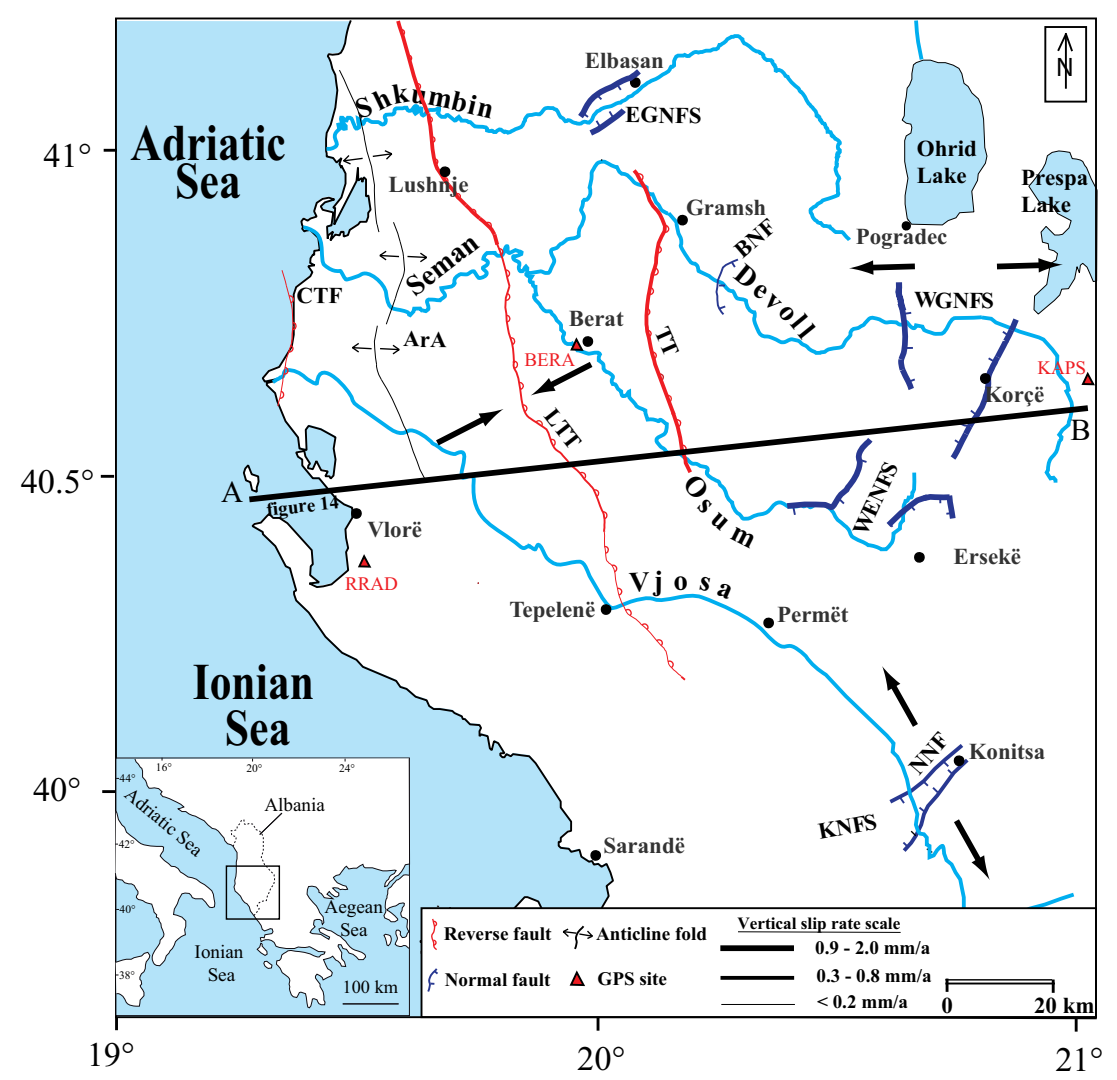

Figure 13. Regional map showing the vertical slip rates of the active faults inferred from incision of river terraces (the whole neotectonic structures inferred in Albania are shown on Figure 1). Thickness of the fault traces is proportional to the valuse of vertical slip rate. Black arrow represents the orientation of the maximum extension and shortening of the present day deformation field of Albania (from Jouanne et al. [2012]). The location of Figure 14 is also shown in the map.

Thus, we estimate at least for the last $25 \mathrm{ka}$ a vertical slip rate of $\sim 0.3 \mathrm{~mm} / \mathrm{a}$ for this fault.

Additionally, the extrapolation of the regional trend of the incision rate towards the Konitsa basin, allows estimating a slip rate of $>0.4 \mathrm{~mm} / \mathrm{a}$ for the NNF and KNFS (Figure 12, Table 2).

5.4. Comparison between seismotectonics and Quaternary fault activity at regional scale

In order to evaluate the extent of the major faults in southern Albania, the vertical slip rates of the faults evidenced in this study and those estimated in previous published works were plotted together on a regional map (Figure 13) (Carcaillet et al. [2009], Fouache et al. [2010b]; Table 2). The neotectonic map of Albania [Aliaj et al. 1996, 2000] and northwestern Greece [Waters 1993] were used as a base for mapping the faults. In this map, the line thickness is proportional to the vertical slip rate of each fault. The results suggest that: a) the largest vertical slip rate of the active faults is associated to the extensional domain in the eastern part of southern Albania; b) the normal faulting linked to the E-W extension of the eastern Albanian graben systems seems more active than the normal faulting linked to the NWSE extension that affect the NW part of Greece; c) the Elbasan Graben Normal Fault System is also very active.
As there are no significant differences between geodetic strain rates and seismological derived strain rates [Jouanne et al. 2012], it is suggested that no aseismic deformation occurs in Albania and active faulting is expected to be linked to a succession of earthquakes. The comparison between the seismic activity of the three well-defined seismic belts [Aliaj 1988, Muço 1998, Aliaj 2000, Sulstarova et al. 2003] and the slip rate of the faults confirms the superficial activity of the faults in the Peshkopia-Korçë earthquake belt and the Vlora-Elbasan-Dibra transverse belt. For the Ionian-Adriatic coastal earthquake belt there is a discrepancy between the high seismic activity and the small evidences of fault activity from our morphotectonic approach. This discrepancy could either be due to a bias induced by the dominance of sedimentation and the absence of preservation of terraces in the zone, or to compressional earthquakes that do not cross the upper part of the crust. Thus, other geophysical or geodetic approach should be used to better constrain this issue.

\subsection{Comparison between present-day deformation and} Quaternary fault activity at regional scale

An estimate of the current displacement along the faults from GPS measurements is not possible due to the small number of GPS sites at the vicinity of the 


\begin{tabular}{|c|c|c|c|c|c|c|c|}
\hline \multirow{2}{*}{$\begin{array}{l}\text { GPS } \\
\text { site }\end{array}$} & \multirow{2}{*}{$\begin{array}{c}\text { Geographical } \\
\text { location }\end{array}$} & \multirow{2}{*}{$\begin{array}{l}\text { Latitude } \\
\left({ }^{\circ} \mathrm{N}\right)\end{array}$} & \multirow{2}{*}{$\begin{array}{l}\text { Longitude } \\
\qquad\left({ }^{\circ} \mathrm{E}\right)\end{array}$} & $\mathrm{Ve}(\mathrm{mm} / \mathrm{a})$ & $\operatorname{Ve}(\mathrm{mm} / \mathrm{a})$ & $\operatorname{Ve}(\mathrm{mm} / \mathrm{a})$ & $\mathrm{Ve}(\mathrm{mm} / \mathrm{a})$ \\
\hline & & & & \multicolumn{2}{|c|}{$\begin{array}{l}\text { respect to ITRF2005 } \\
\text { [Altamimi et al. 2007] }\end{array}$} & \multicolumn{2}{|c|}{ respect to BERA site } \\
\hline RRAD & Sea border & 19.4938 & 40.3654 & 23.748 & 17.168 & 1.3 & 2.0 \\
\hline BERA & Berat & 19.9455 & 40.7082 & 22.405 & 15.181 & 0.0 & 0.0 \\
\hline KAPS & Greek border & 21.0404 & 40.6226 & 25.005 & 10.365 & 2.6 & 4.8 \\
\hline
\end{tabular}

Table 3. Velocities of GPS sites in a ITRF2005 [Altamimi et al. 2007] (from Jouanne et al. [2012]). Ve and Vn are respectively the component of velocity towards $\mathrm{E}$ and $\mathrm{N}$. See text for discussion of the velocity with respect to BERA at the hanging wall of the LTT.

faults and their elastic loading during seismic cycle. Nonetheless the present-day deformation rates deduced from GPS velocities [Jouanne et al. 2012] and our study outline the major role of the LTT: this fault is more than $120 \mathrm{~km}$ long (Table 2) and is also the presentday boundary between the western domain affected by the Apulia/Albanide collision and the eastern domain affected by a displacement with a component toward the South [Jouanne et al. 2012]. Our geomormophological study and GPS data also confirm the major activity of the normal fault system of eastern Albania.

A comparison between the displacements of three GPS sites (Table 3) located on the three domains limited by the LTT and the normal fault system of Albania allows the following considerations:

On a regional West-East cross-section (Figure 14), the GPS measurements indicate: 1) a displacement component towards the East of $1.3 \mathrm{~mm} / \mathrm{a}$ between the western coast (RRAD site) and a station located at the hanging-wall of the LTT (BERA site); 2) a displacement component towards the East of $2.6 \mathrm{~mm} / \mathrm{a}$ between the Internal Albanides (KAPS site) and the BERA station. The horizontal shortening associated with the active thrust faults along this cross section can also be estimated by using the slip rate inferred from the incision rate and a mean dip of $30^{\circ}$ for the thrusts of ArA and LTT, and a dip of $60^{\circ}$ for the normal faults of WENFS; we found a shortening of $\sim 0.6$ $\mathrm{mm} / \mathrm{a}$ between the coast and Berat city, and an extension between 0.9 and $1.3 \mathrm{~mm} / \mathrm{a}$ associated with the normal fault systems of eastern Albania. As there are no significant differences between geodetic strain rates and seismological derived strain rates [Jouanne et al. 2012], the discrepancies between GPS measurements and geomorphological estimates do not mean that the interseismic velocities of the Albania active

West

East
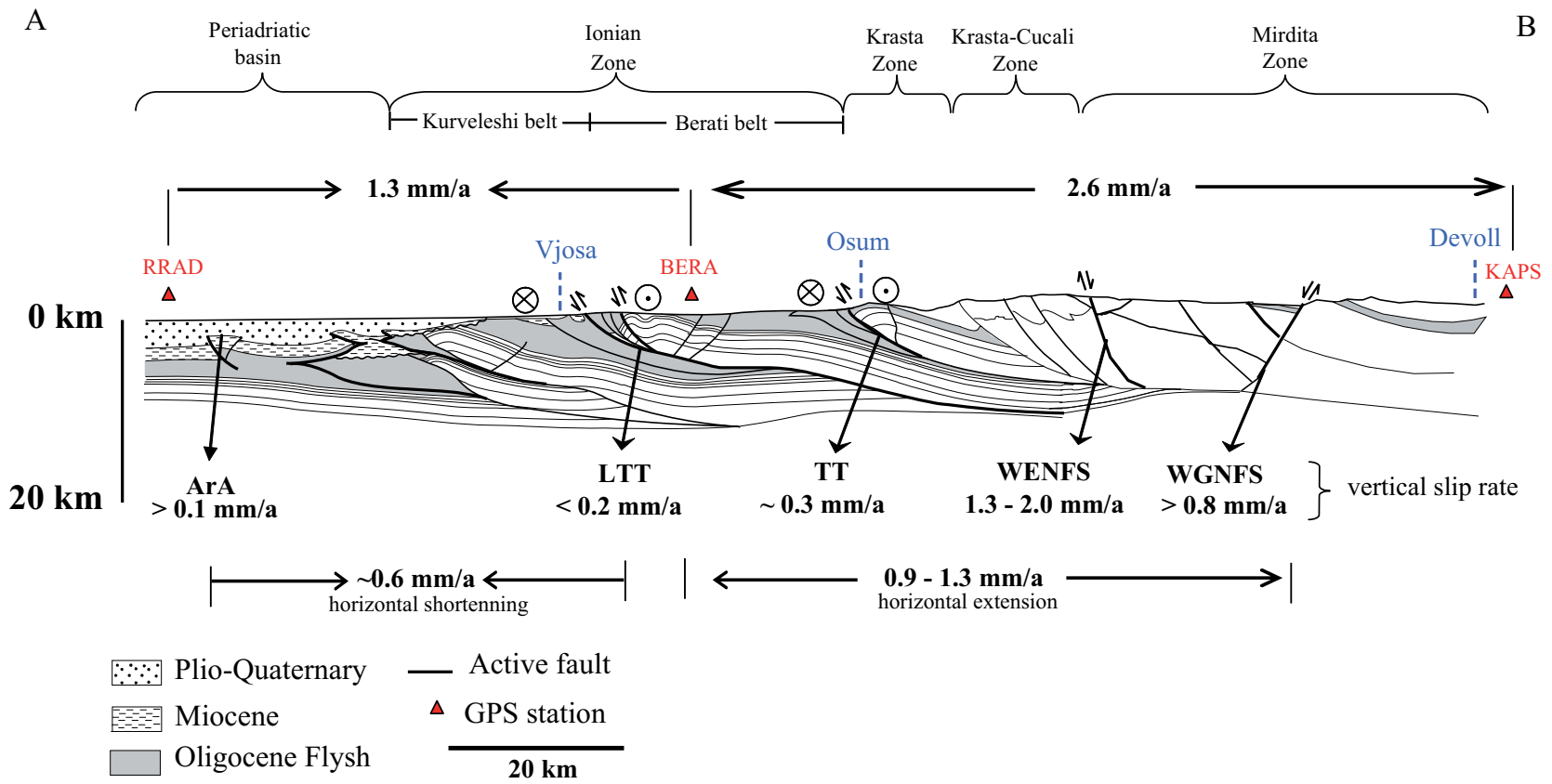

Figure 14. Simplified structural cross-section through the southern Albanides adapted from, the Geological Map of Albania [SHGJSH 2003], Kilias et al. [2001], Roure et al. [2004] and Carcaillet et al. [2009]. The neotectonic framework is modified from Aliaj et al. [1996, 2000] and the strike-slip component deduced from GPS network [Jouanne et al. 2012]. Values of relative displacements between GPS sites are indicated above GPS stations. Vertical slip rates calculated in the present study are shown, as well as, the horizontal shortening and extension estimated from the slip rate. 
faults are unsteady throughout the seismic cycle. These differences could be caused by the under-estimation of vertical slip rates in the sedimentation zones in this study, or by the distribution of the deformation on other active structures not analyzed in this study.

North-South components of displacement evidenced by the three GPS stations are larger than the East-West components, implying a dextral oblique slip component along most of the active faults. These dextral components cannot be estimated from the vertical incision of the river, and no faults clearly horizontally offset the river profiles.

\section{Conclusion}

In this study, we quantified the spatial and temporal evolution of the incision rate along four rivers in southern Albania. From this quantification, we identified local shifts in the regional trend of incision rates associated with Quaternary faults. These incision rate shifts allowed the quantification of the vertical slip rate of eight active faults in the area. Most of them were already considered as potential seismogenic sources [Aliaj et al. 2000, Sulstarova et al. 2003, Basili et al. 2013 and the SHARE database] and this study furnishes more precisions: 1) the thrust at the footwall of the Berati belt (LTT) is active on a length of more than 120 kilometers and its vertical slip rate is $\sim 0.8 \mathrm{~mm} /$ a close to Lushnje in the North and strongly decreases towards the South; 2) the Tomorrica Thrust (TT) at the base of one of the highest summit of Albania is active with a vertical slip rate of $0.3 \mathrm{~mm} / \mathrm{a}$ and on a length of at least $50 \mathrm{~km}$; 3) the Elbasan Graben Normal Fault System (EGNFS) has a vertical slip rate $\geq 1 \mathrm{~mm} / \mathrm{a}$ on a fault segment of at least 5-km-long; 4) the Graben system of southeastern Albania is very active on its western side. The fault system is formed by several segments with a length of at least $20 \mathrm{~km}$. The vertical slip rates of the segments located West of Ersekë (WENFS) vary between 1.3 and $2.0 \mathrm{~mm} / \mathrm{a}$, while that for the segments located West of Korçë (WGNFS) are $\geq 0.8 \mathrm{~mm} / \mathrm{a}$; 5 ) the vertical slip rate of the normal fault system of northwestern Greece (NNF and KNFS) is $\geq 0.4 \mathrm{~mm} / \mathrm{a}$ along fault segments of at least $15 \mathrm{~km}$ lenght. Our field work has detected an unknown active fault that reactivates the base of the Mirdita zone in the middle reach of the Devoll river (BNF). The vertical slip rate of this fault is $\sim 0.3 \mathrm{~mm} / \mathrm{a}$.

Finally, the results of this study also put in evidence that the fluvial incision is maximal at the transition between the domains of extensional and compressional tectonics, suggesting that the regional uplift is maximal in this zone and reaches more than $1 \mathrm{~mm} / \mathrm{a}$.
Acknowledgements. The authors thank the NATO SFP 977993 and the Science for Peace team to have supported this work. This publication was also made possible through support provided by the IRD-DPF. O.G. thanks to INQUA - Terpro for the grant to participate in the 2nd INQUA-ICGP 567 International Workshop on Active Tectonics, Earthquake Geology, Archaeology and Engineering.

\section{References}

Aliaj, Sh. (1971). Adriatic depression and its structures in the light of geophysical data, Bull. USHT, Ser. Shk. Nat., 3, 25-41 (in Albanian).

Aliaj, Sh. (1988). Neotectonic and seismotectonic of Albania, Ph.D. thesis, Archive of Institute of Seismology, Tirana, Albania (in Albanian).

Aliaj, Sh. (1991). Neotectonic structure of Albania, Albania Journal of Natural and Technical Sciences, 4, 79-98.

Aliaj, Sh., V. Melo, A. Hyseni, J. Skrami, Ll. Mëhillka, B. Muço, E. Sulstarova, K. Prifti, P. Pashko and S. Prillo (1996). Neo-tectonic map of Albania in scale 1:200,000, Archive of Seismology Institute, Tirana, Albania (in Albanian).

Aliaj, Sh. (1999). Transverse fault in Albania Orogen front, Albania Journal of Natural and Technical Sciences, 6, 121-132.

Aliaj, Sh. (2000). Neotectonics and seismicity in Albania, In: S. Melo, S. Aliaj and I. Turku (eds.), Geology of Albania, Beitrage zur regionalen Geologie der Erde, Gebruder Borntrager, Berlin, 28, 135-178.

Aliaj, S., E. Sulstarova, B. Muço and S. Koçiu (2000). Seismotectonic map of Albania in scale 1:500,000, Archive of Institute of Seismology, Tirana, Albania (in Albanian).

Aliaj, Sh. (2004). Seismic source zones in Albania. NATO Sciences for peace programme, Project no. 972342 "Seismotectonis and Seismic hazard Assesment in Albania" Final report.

Aliaj, Sh. (2006). The Albanian Orogen: Convergence zone between Eurasia and the Adria microplate, In: N. Pinter, G. Grenerczy, J. Weber, S. Stein and D. Medak (eds.), The Adria Microplate: GPS Geodesy, Tectonics and hazards, NATO Science Series, IV / 61 Earth and Environmental Sciences, 133-149.

Altamimi, Z., X. Collilieux, J. Legran, B. Garayt and C. Boucher (2007). ITRF2005: A new release of the International Terrestrial Reference Frame based on time series of station positions and Earth Orientation Parameters, J. Geophys. Res., 112, B09401; doi:10.1029/2007JB004949/.

Avouac, J.-P. (1993). Analysis of scarp profiles: evaluation of errors in morphologic dating, J. Geophys. Res., 98, 6745-6754.

Basili, R., V. Kastelic, M.B. Demircioglu, D. Garcia 
Moreno, E.S. Nemser, P. Petricca, S.P. Sboras, G.M. Besana-Ostma, J. Cabral, T. Camelbeeck, R. Caputo, L. Danciu, H. Dornac, J. Fonseca, J. Garcia-Mayordomo, D. Giardini, B. Glavatovic, L. Gulen, Y. Ince, S. Pavlides, K. Sesetyan, G. Tarabusi, M.M. Tiberti, M. Utkucu, G. Valensise, K. Vanneste, S. Vilanova and J. Wössner (2013). The European Database of Seismogenic Faults (EDSF) compiled in the framework of the Project SHARE, http: / / diss.rm.ingv.it/ share-edsf/; doi:10.6092/INGV.IT-SHARE-EDSF.

Burbank, D.W., and R.S. Anderson (2001). Tectonic Geomorphology, Blackwell, Great Britain, 274 pp.

Caputo, R., L. Salviulo and M. Bianca (2008). Late Quaternary activity of the Scorciabuoi Fault (southern Italy) as inferred from morphotectonic investigations and numerical modelling, Tectonics, 27, TC3004; doi:10.1029/2007TC002203.

Caputo, R., M. Bianca and R. D’Onofrio (2010). Ionian marine terraces of southern Italy: Insights into the Quaternary tectonic evolution of the area, Tectonics, TC4005; doi:10.1029/2009TC002625.

Carcaillet, J., J.L. Mugnier, R. Koçi and F. Jouanne (2009). Uplift and active tectonics of southern Albania inferred from incision of alluvial terraces, Quaternary Research, 71 (3), 465-476.

Carminati, E., C. Doglioni, A. Argnani, G. Carrara, C. Dabovski, N. Dumurdzanov, M. Gaetani, G. Georgiev, A. Mauffret, S. Nazai, R. Sartori, V. Scionti, D. Scrocca, M. Séranne, L. Torelli and I. Zagorchev (2004). TRANSMED Transect III, In: W. Cavazza, F. Roure, W. Spakman, G.M. Stampfli and P. Siegle (eds.), The TRANSMED Atlas - The Mediterranean region from Crust to Mantle, Springler, Berlin Heidelberg.

Carozza, J.-M., and B. Delcaillau (1999). Geomorphic record of Quaternary tectonic activity by Alluvial terraces: example from the Tet basin (Roussillon, France), Earth and Planetary Sciences, 329, 735-740.

Clark, P.U., A.S. Dyke, J.D. Shakun, A.E. Carlson, J., Clark, B. Wohlfarth, J.X. Mitrovica and S.W. Hostetler (2009). The Last Glacial Maximum, Science, 325, 710-714.

Copley, A., F. Boait, J. Hollingsworth, J. Jackson and D. McKenzie (2009). Subparallel thrust and normal faulting in Albania and the roles of gravitational potential energy and rheology contrasts in mountain belts, J. Geophys. Res., 114, B05407; doi:10.1029/2008 JB005931.

Dumurdzanov, N., T. Serafimovski and B.C. Burchfiel (2005). Cenozoic tectonics of Macedonia and its relation to the South Balkan extensional regime, Geosphere, 1 (1), 1-22.

Fouache, E., S. Desruelles, M. Magny, A. Bordon, C. Oberweiler, C. Coussot, G. Touchais, P. Lera, A-M.
Lézine, L. Fadin and R. Roger (2010a). Paleogeographical reconstruction of Lake Maliq (Korça Basin, Albania) between 14000 BP and 2000 BP, J. Archaeol. Sci., 37, 525-535.

Fouache, E., E. Vella, L. Dimo, G. Gruda, J.-L. Mugnier, M. Dènefle, O. Monnier, M. Hotyat and E. Huth (2010b). Shoreline reconstruction since the Middle Holocene in the vicinity of the ancient city of Apollonia (Albania, Seman and Vjosa deltas), Quaternary International, 216, 118-128.

Fourcart, J. (1921). Carte Géologique des confines Albanais. 1:200,000, published by the Service Géographique de l'Armée Française.

Fuller, I.C., M.G. Macklin, J. Lewin, D.G. Passmore and A.G. Wintle (1998). River response to high-frequency climate oscillations in southern Europe over the past 200 k.y., Geology, 26 (3), 275-278.

Gosse, J.C., and F.M. Phillips (2001). Terrestrial in situ cosmogenic nuclides: theory and application, Quaternary Science Review, 20, 1475-1560.

Guzmán, O., J.-L. Mugnier, R. Koçi, R. Vassallo, J. Carcaillet, F. Jouanne and E. Fouache (2011). Active tectonics of Albania inferred from fluvial terraces geometries, 2nd INQUA-ICGP 567 International Workshop on Active Tectonics, Earthquake Geology, Archaeology and Engineering, Proceedings, 2, 66-69.

Guzmán, O. (2013). Timing and Dynamics of river terraces formation in moderate uplifted ranges: the example of Venezuela and Albania, Ph.D. thesis, Université de Grenoble, France, 269 pp.

Hamlin, R., J. Woodward, S. Black and M.G. Macklin (2000). Sediment fingerprinting as a tool for interpreting long-term river activity: the Voidomatis basin, Northwest Greece, In: 581 I.D.L. Foster (ed.), Tracers in Geomorphology, John Wiley and Sons, Chichester, 473-501.

Institutin Topografik te Ushtrise Tirane (1959-1990). Topographic maps of Socialist Republic of Albania in scale 1:25,000, Archive of Institute of Seismology, Tirana, Albania (in Albanian).

Jouanne, F., J.L. Mugnier, R. Koçi, S. Bushati, K. Matev, N. Kuka, I. Shinko, S. Kociu and L. Duni (2012). GPS constraints on current tectonics of Albania, Tectonophysic, 554, 50-62; doi:10.1016/j.tecto.2012.06.008.

Kallel, N., J.C. Duplessy, L. Labeyrie, M. Fontugne, M. Paterne and M. Montacer (2000). Mediterranean pluvial periods and Sapropel formation over the last 200,000 years, Palaeogeography, Palaeoclimatology, Palaeoecology, 157, 45-58.

Kastelic, V., R. Basili, L. Duni and R. Koçi (2012). Contributions to European Database of Seismogenic fauts, within the EU-FP7 Project Seismic hazard har- 
monization in Europe (SHARE); http: / / diss.rm.ingv. it/share-edsf/.

Kilias, A., M. Tranos, D. Mountrakis, M. Shallo, A. Marto and I. Turku (2001). Geometry and kinematics of deformation in the Albanian orogenic belt during the Tertiary, Journal of Geodynamics, 31 (2), 169-187.

Kiratzi, A.A. (2011). The 6 September 2009 Mw5.4 Earthquake in Eastern Albania - FYROM Border: Focal Mechanisms, Slip Model, ShakeMap, Turkish Journal of Earth Sciences, 20, 475-488.

Koçi, R. (2007). Geomorphology of quaternary deposits of Albanian rivers, Ph.D. thesis, Archive of Institute of Seismology, Tirana, Albania (in Albanian).

Lewin, J., M.G. Macklin and J.C. Woodward (1991). Late Quaternary fluvial sedimentation in the Voidomatis basin, Epirus, Northwest Greece, Quaternary Research, 35, 103-115.

Macklin, M.G., I.C. Fuller, J. Lewin, G.S. Maas, D.G. Passmore, J. Rose, J.C. Woodward, S. Black, R.H.B. Hamlin and J.S. Rowa (2002). Correlation of fluvial sequences in the Mediterranean basin over last 200 $\mathrm{ka}$ and their relationship to climate change, Quaternary Science Reviews, 21, 1633-1641.

Mason, D.P.M., T.A. Little and R.J. Van Dissen (2006). Rates of active faulting during late Quaternary fluvial terrace formation at Saxton River, Awatere fault, New Zealand, Geological Society of America Bulletin, 118, 1431-1446.

Melo, V. (1961). Neotectonic in the Elbasan-Peqin area from Shkumbin terraces, Bul. Univ. Sht. Shkencave Natyrore II (in Albanian).

Meyer, G.A., S.G. Wellsa and A.J.T. Jull (1995). Fire and alluvial chronology in Yellowstone National Park: climate and intrinsic controls on Holocene geomorphic processes, Geological Society of America Bulletin, 107, 1211-1230.

Muceku, B., P. Van der Beek, M. Bernet, P. Reinerrs, G. Mascle and A. Tashko (2008). Thermochronological evidence for Mio-Pliocene late orogenic extension in the north-eastern Albanides (Albania), Terra Nova, 20, 180-187.

Muço, B. (1994). Focal mechanism solutions of earthquakes for the period 1964-1988, Tectonophysics, 231 (4), 311-323.

Muço, B. (1998). Catalogue of ML $\geq 3$ earthquakes in Albania from 1976 to 1995 and distribution of seismic energy released, Tectonophysics, 292, 311-319.

Niewland, D.A., B.C. Oudemayer and U. Valbona (2001). The tectonic development of Albania: explanation and prediction of structural styles, Marine and Petroleum Geology, 18, 161-177.

Pazzaglia, F.J., and M.T. Brandon (2001). A fluvial record of long-term steady-state uplift and erosion across the Cascadia forearc high, western Washington state, American Journal of Science, 301, 385-431.

Prifti, K. (1981). Formation of the quaternary valley of the upper Vjosa river, Archive of Institute of Seismology, Tirana, Albania (in Albanian).

Ramsey, B. (2009). Bayesian analysis of radiocarbon dates, Radiocarbon, 51 (1), 337-360.

Robertson, A., and M. Shallo (2000). Mesozoic-Tertiary tectonic evolution of Albania in its regional eastern Mediterranean context, Tectonophysics, 316 (3), 197-254.

Roure, F., S. Nazaj, K. Mushka, I. Fili, J.P. Cadet and M. Bonneau (2004). Kinematic evolution and petroleum systems - An appraisal of the Outer Albanides, In: K.R. McClay (ed.), Thrust tectonics and hydrocarbon systems, AAPG memoir, 82, 474-493.

SHGJSH (2003). Geological Map of Albania in scale 1:200,000, Geological Service of Albania, Tirana, Albania, 2nd ed. (in Albanian).

Sorel, D., G. Bizon, Sh. Aliaj and L. Hasani (1992). Calage stratigraphique de l'âge et durée des phases compressives des Hellenéides extrens (Grèce nordoccidentales et Albanie), du Miocène à l'actuel, Bull. Soc. Géologique France, 163, 447-454.

Stratton Noller, J., J.M. Sowers and W.R. Lettis (2000). Quaternary Geochronology: Methods and Applications, AGU Reference Shelf Series, vol. 4, American Geophysical Union, Washington D.C.

Sulstarova, E. (1986). Mechanism of earthquakes and field of present-day tectonic stresses in Albania, Ph.D. thesis, Archive of Institute of Seismology, Tirana (in Albanian).

Sulstarova, E., V., Peçi and P. Shuteriqi (2000). Vlora-Elbasani-Dibra (Albania) transversal fault zone and its seismic activity, Journal of Seismology, 4, 117-131.

Sulstarova, E., S. Kociaj, B. Muco and V. Peci (2003). The Albanian earthquakes catalogue for historical and instrumental data with magnitude Mš4.5, Internal Report (behalf of NATO Project Seismotectonic and Seismic Hazard Assessment in Albania, 1999-2002), Seismological Institute, Tirana, Albania.

Tagari, Dh. (1993). Étude néotectonique et seismotectonique des Albanides: Analyse des déformations et géodynamique du Langhien à l'actuel, Ph.D. thesis, Univ. Paris-Sud, Orsay, France.

Tagari, Dh., P. Vergely and Sh. Aliaj (1993). Tectonique polyphasée plio-quaternarire en Albanie orientale (région de Korçë-Pogradeci), Bull. Soc. Géologique France, 164 (5), 727-737.

Vassallo, R., J.-F. Ritz, R. Braucher and S. Carretier (2005). Dating faulted alluvial fans with cosmogenic ${ }^{10} \mathrm{Be}$ in the Gurvan Bogd mountain range (GobiAltay, Mongolia): climatic and tectonic implications, 
Terra Nova, 17, 278-285.

Wagner, B., H. Vogel, G. Zanchetta and R. Sulpizio (2010). Enviromental change within the Balkan region during the past ca. $50 \mathrm{ka}$ recorded in the sediments from lakes Prespa and Ohrid, Biogesciences, 7, 3187-3198.

Waters, D.W. (1993). The tectonic evolution of Epirus, N.W. Greece, PhD thesis, Univ. of Cambridge, Cambridge, England.

Wegmann, K.W., and F.J. Pazzaglia (2002). Holocene strath terraces, climate change, and active tectonics; the Clearwater River basin, Olympic Peninsula, Washington State, Geological Society of America Bulletin, 114 (6), 731-744.

Wegmann, K.W., and F.J. Pazzaglia (2009). Late Quaternary fluvial terraces of the Romagna and Marche Apennines, Italy, Quaternary Science Reviews, 28, 137-165.

Wesnousky, S.G., R. Aranguren, M. Rengifo, L.A. Owen, M.W. Caffe, M.K. Murari and O. Pérez (2012). Toward quantifying geomorphic rates of crustal displacement, landscape development, and the age of glaciation in the Venezuelan Andes, Geomorphology, 141-142, 99-113.

Woodward, J.C., R.B.H. Hamlin, M.G. Macklin, P. Karkanas and E. Kotjabopoulou (2001). Quantitative sourcing of slackwater deposits at Boila rockshelter: A record of late-glacial flooding and palaeolithic settlement in the Pindus Mountains, northern Greece, Geoarchaeology, 16 (5), 501-536.

Woodward, J.C., R.H.B. Hamlin, M.G. Macklin, P.D. Hughes and J. Lewin (2008). Glacial activity and catchment dynamics in Northwest Greece: longterm river behaviour and the slackwater sediment record for the last glacial to interglacial transition, Geomorphology, 101, 44-67.

\footnotetext{
*Corresponding author: Oswaldo Guzmán,

Universidad Simon Bolivar, Departamento de Ciencias

de la Tierra, Caracas, Venezuela; email: guzmano@usb.ve.

(C) 2013 by the Istituto Nazionale di Geofisica e Vulcanologia. All

rights reserved.
} 